\title{
Cumhurbaşkanlığı Kararnamelerinin Konu Bakımından Yetki Sınırları
}

\author{
Halit YıImaz ${ }^{*}$
}

\section{Öz}

2017 yılında yapılan Anayasa değişiklikleri ile halk tarafindan seçilen ve yürütme organının makamında tecessüm ettiği Cumhurbaşkanına herhangi bir kanuna dayanmak zorunda olmayan kararnameler çıkarma yetkisi vermiştir. Söz konusu kararnamelerin kanunları değiştirme gücü bulunmasa da Cumhurbaşkanı kararnamelerle özerk bir düzenleme yetkisine sahip olmuştur. Bu açıdan bakıldığında kanun ve kararname arasındaki normatif ilişki kamu hukuku gündeminde önemli konu olarak bir yer almıştır. Bu çalışmanın amacı kanun ve kararname ilişkisini düzenleyen Anayasa hükümleri bağlamında kararnamelerin konu bakımından yetki sınırlarını açıklamaktır.

\section{Anahtar Kelimeler}

Anayasa değişikliği, Yasama işlevi, Yürütme işlevi, Cumhurbaşkanlığı kararnameleri, Özerk düzenleme yetkisi

\section{Constitutional Limitations on the Subject of Presidential Decrees}

\begin{abstract}
Amendments made to the Turkish Constitution in 2017 empower the President of the Republic, who is elected by the entire nation and embodies the whole executive branch, to enact decrees which are not based on any legislation. Although these decrees do not have the power to change the legislation, the President has autonomous regulatory authority. In this regard, normative relations between legislation and decrees has become one of the major predicaments of Turkish public law. The aim of this study is to explain the regulative boundaries of decrees in context with the constitutional provisions regulating the relationship between the law and decrees.
\end{abstract}

\section{Keywords}

Amendments to constitution, Legislative function, Executive function, Presidential decrees, Autonomous regulatory power

Sorumlu Yazar: Halit Yılmaz (Prof. Dr.), Antalya Bilim Üniversitesi, Hukuk Fakültesi, İdare Hukuku Ana Bilim Dalı, Antalya, Türkiye. E-posta: halit.yilmaz@antalya.edu.tr ORCID: 0000-0002-0008-318X 


\section{Extended Summary}

The principal objective of the constitutional amendments of 16 April 2017, was to establish a presidential government. An essential constitutional measure of this new administrative system is the 'Presidential Decrees', a new regulatory instrument of the executive body. In Turkish constitutional tradition, the regulatory power of governments, which must rely on legislation, has always been derivative. The constitutional amendment created a strong exception in this deep-rooted tradition, granting power to the President to issue decrees without having to rely on legislation.

Ergo, the Constitutional amendments concerning Presidential Decrees requires us to redefine and explicate the rulemaking powers of the Executive. However, this does not appear to be an easy task due to the ambiguity and vagueness of the amendments introduced. A new Turkish public law practice is beginning to generate contradictory interpretations concerning the legal circumference of these presidential decrees; a matter which is yet to be conclusively decided by the Constitutional Court.

Legislation cannot be annulled, voided, nor amended by Presidential Decrees. Neither can they determine matters regulated by legislation. While these were clearly established as constitutional principles by the Constitution, the delinquency remains with the ill-defined legal boundaries of Presidential Decrees.

Article 104/17 of the Constitution states that, 'The President of the Republic may issue presidential decrees on matters relating to the executive power.' Since the Constitution fails to concretize matters falling within the Executive's competence, the most apparent problem in this provision is the difficulty in determining the actual legal circumference of executive power.

Four subject-matters, relating to the reorganizational aspect of the administrative office, have been established as within the regulatory power of Presidential Decrees, but at face value it is impossible to identify any other subject-matters that could be determined as within the Executive's competence. The Constitution's silence on whether or not the Legislative body could legislate on these subject-matters (Arts. $104 / 9,106 / 11,108 / 4,118 / 6$ ) creates further uncertainties. The doctrine is divided on this topic. If we accept that these do not fall within the Legislative's competence, then the Constitution can be said to have created an exception to these subjectmaters; which would mean the derogation of the Legislative's power to regulate by legislation.

Aside from social and economic rights, Presidential Decrees cannot regulate on matters relating to fundamental rights and freedoms. The primary objective of this limitation is to continue with the legislative safeguarding of fundamental rights and freedoms. Nevertheless, this limitation, too, is not decisively clear. In particular, the 
arrangement and regulating powers of ministries, the prospect of Presidential Decrees remaining mute on matters concerning fundamental rights and freedoms appears infeasible. 


\section{Cumhurbaşkanlığı Kararnamelerinin Konu Bakımından Yetki Sınırları}

\section{Giriş}

21/01/2017 tarih ve 6771 sayılı Türkiye Cumhuriyeti Anayasasında Değişiklik Yapılmasına Dair Kanun ${ }^{1}$ ile Anayasa sistemimizde parlamenter hükümet sistemi terk edilmiş, yürütme gücü halk tarafından doğrudan seçilen Cumhurbaşkanında toplanmıştır.

Anayasa değişikliği yürütme organını yeni bir yapıya kavuştururken "Cumhurbaşkanlığı kararnamesi" ${ }^{2}$ adını verdiği bir işlem ile yürütme organının düzenleme yetkisinin kapsam ve niteliğinde de yenilikler meydana getirmiştir. Cumhurbaşkanlığı kararnamesi dışında, Anayasa değişikliğinden sonra yürütme organının bir kanuna dayanarak diğer adlar altında tesis edeceği düzenleyici işlemlerin kapsam ve niteliği bakımından herhangi bir yenilik bulunmamaktadır. Yine olağanüstü dönemlerden çıkarılabilecek olan olağanüstü hâl Cumhurbaşkanlığ 1 kararnamelerinin geçmişteki olağanüstü hâl kanun hükmünde kararnamelerinden büyük bir farkı yoktur. Bu çalışmada sadece Anayasa' da "kararname" adıyla düzenlenen Cumhurbaşkanı işlemleri incelenecek olup olağanüstü hâl kararnameleri ve Cumhurbaşkanının diğer adlar altında tesis ettiği idari işlemleri kapsam dışı bırakılacaktır.

Anayasa değişikliği yürütme organının düzenleme yetkisini yeni bir boyuta taşırken, doğal olarak bu yetkinin konusunu da sınırlamaya çalışmıştır. Yürütme organının düzenleme yetkisinin yasama yetkisi karşısındaki konumunun tartışmalara yol açmayacak açıklıkta düzenlenmesi gerekir. Bu çalı̧̧manın esas amacı bu olmasa da ele alınacak olan Anayasa değişikliklerinin söz konusu açıklığın sağlanması için gereken asgari özen ve hukuk aklını içerip içermediği bu çalışmanın sonunda ortaya çıkacaktır. Esas amacımız ise kanun ve kararname ilişkisi bakımından Anayasa'da yer alan düzenlemeleri yorumlamak ve bu bağlamda kararname çıkarma yetkisinin konu sınırını belirmeye çalışmaktır. Bu amaç açısından bakıldığında kararnamelerin yargısal denetimi konusunun inceleme dışında kalması da doğaldır.

Kamu hukuku geleneğimizin köklü ilkelerinden birisi yürütme işlevinin türev, tali ya da ikincil bir işlev olduğuna işaret eden "idarenin kanuniliği" ilkesidir. Karşı bir görüşü destekleyen unsurlar mevcut olsa da ele alacağımız Anayasa düzenlemeleri, kararnamelerin bir kanuna dayanmak zorunda olmaması açısından, idarenin kanuniliği ilkesinde kapsamlı bir istisna getirmiştir. Kararname çıkarma yetkisinin konu bakımından sınırlarının kararnamenin bir kanuna dayanmak zorunda olup olmadığından bağımsız bir şekilde ele alınması mümkün değildir. Çünkü, eğer kararnameler bir kanuna dayanmak zorunda ise konu bakımından yetki sınırlarını belirleme güçlüğü büyük ölçüde aşılabilir. Yine benzer sebeplerle düzenleme yetkisinin konu bakımından

RG 11.02.2017/29976.

Zorunlu olmadığı sürece metin içinde "Cumhurbaşkanlığı kararnameleri” yerine kısaca "kararnameler" ifadesi kullanılacaktır. 
sınırları, düzenleyici işlemin normlar hiyerarşindeki yeriyle doğrudan ilgilidir. Normun gücü hem diğer normlarla ilişkisini belirler hem de konu sınırlarını anlamamıza yardımc1 olur (I).

Eğer kararnameler asli bir düzenleme yetkisinden doğacaksa, bu durum yürütme ve yasamanın düzenleme yetkisi bakımından eşit ve aynı güçte olmasa da belli bir ortaklığa tabi kılındığı anlamına gelir. Bu bakımdan yasama ve yürütmenin düzenleme yetkisinin karşı1lıklı olarak konu bakımından belirgin sınırlara kavuşturulması gerekir. Anayasa bu sınırları belirlerken kararname için mahfuz, kanun için münhasır alanların varlığına ilişkin tartışmalara yol açmakla kalmamış (II); aynı zamanda yasama ve yürütme arasında ortak düzenleme alanı oluşturarak konuya daha da karmaşık bir boyut kazandırmıştır (III).

\section{Yeni Bir Norm Kategorisi Olarak Cumhurbaşkanlığı Kararnameleri}

İdarenin kanuniliği ilkesinden sapmalar kamu hukukumuzda yeni bir olgu değildir. Geçmişte olağanüstü hâl kanun hükmünde kararnameleri ile Cumhurbaşkanlığı Genel Sekreterliğinin kuruluşu, teşkilat ve çalışma esasları ile personel atama işlemleri konulu Cumhurbaşkanlığı kararnamesi bir kanuna dayanmak zorunda olmayan düzenleyici işlemlerdi. Olağanüstü hâlin istisnailiği ve bu dönemde çıkarılan kanun hükmünde kararnamelerin yasama organı tarafindan belirlenen sürede onaylanıp onaylanmama noktasında ivedilikle değerlendirilecek olması; Cumhurbaşkanlı̆̆ı kararnamesinin ise sadece Cumhurbaşkanlığının öz teşkilatını düzenlemek ve kişilere yönelik herhangi bir hak veya yükümlülük doğurmaması bakımlarından kanunilik ilkesinin geniş bir istisna rejime sahip olmadığı düşünülebilirdi. Ele alacağımız Anayasa değişikliğinden sonra, olağanüstü hâl rejimiyle sınırlı olmayacak şekilde kanunilik ilkesine dönük daha kapsamlı bir istisnanın ortaya çıkıp çıkmadığı tartışılmalıdır (A).

Aksine bir düzenleme bulunmadığı sürece, idarenin düzenleme yetkisinin bir kanuna dayandığı durumlarda düzenleyici işlemlerin kanun gücünde olmadığı rahatlıkla açıklanabilir. Dolayısıyla, kanunilik ilkesinden bağımsız olmayan bir başka konu kararnamelerin normlar hiyerarşisindeki yeridir. Eğer kararnameler bir kanuna dayanmak zorunda değilse bunların norm gücünün belirlenmesi gerekecektir (B).

\section{A. İdarenin Kanuniliği İlkesi Bakımından Cumhurbaşkanı Kararnameleri}

İdari işlevin kanuna dayanması zorunluluğunu ifade eden "idarenin kanuniliği ilkesi”, Anayasa'nın 8. maddesindeki "Yürütme yetkisi ve görevi, Cumhurbaşkanı tarafindan, Anayasaya ve kanunlara uygun olarak kullanilır ve yerine getirilir." ve 123/1. maddesindeki idarenin kuruluş ve görevlerinin "kanun" ile düzenleneceği kuralı ile sabittir. Özellikle Anayasa'nın 8. maddesi hükmü Anayasa değişikliğinden önceki durumda, yürütmenin bir "görev" olduğuna ve özerk düzenleme yetkisinin 
bulunmadığına ilişkin temel dayanaklardan birisi olarak görülüyordu. Bu maddede yürütmenin "yetki" olarak nitelendirilmesi ise bir kanuna dayanmak zorunda olmadan Cumhurbaşkanlığı Genel Sekreterliğine ilişkin Cumhurbaşkanlığı kararnamesi ve olağanüstü hâlde kanun hükmünde kararname çıkarma yetkisini ifade etmekten öte bir anlam taşımıyordu³ ${ }^{3}$ Bugün idarenin kanuniliği ilkesini ifade eden Anayasa düzenlemeleri ilk haliyle varlığını sürdürdüğüne ve kararname çıkarma yetkisinin kanuna dayanmak zorunda olmadığı konusunda Anayasa'da açık bir hüküm bulunmadığına göre, kararname çıkarılması için en azından bir yetki kanuna ihtiyaç olduğunun ileri sürülmesi uç bir görüş olarak nitelendirilemez.

Yıldırım'a göre, Anayasa değişikliğinden sonra idarenin düzenleme yetkisinin bir kanuna dayanma ve ondan kaynaklanma zorunluluğu gevşemiş olmakla birlikte tamamen ortadan kalkmış sayılmaz. Buna göre, Anayasa' da konuları özel olarak belirlenmiş kararnameler (md. 104/9, 106/11., 108/4., 118/6., 123/3) söz konusu olduğunda düzenleme yetkisi doğrudan Anayasa'nın ilgili maddelerinden kaynaklanır ve dolayısıyla bir kanuna dayanmak zorunda değildir. Buna karşın, Anayasa’nın 104/17. maddesinde yürütme yetkisine ilişkin konularda çıkarılacak olan kararnamelerin mutlaka bir yetki kanununa dayanması gerekecektir. Özellikle Anayasa Mahkemesinin 2013 yılından bugüne verdiği kararlar çerçevesinde ${ }^{4}$ kanunla yapılan yetkilendirme için düzenleme konusunun detaylarına kanunda yer verilmesine gerek kalmamış olup sadece konuyu belirleyen bir yetkilendirme ifadesi yeterli olacaktır. Anayasa açıkça kanuna dayanma zorunluluğu bulunmadığını düzenlemediği sürece, kararnameler için kanunla yetkilendirme gereği ortadan kalkmaz'. Yıldırım'ın bu gerekçelerine Anayasa'nın 161/7. maddesindeki “Merkezî yönetim bütçesiyle verilen ödenek, harcanabilecek tutarın sınırını gösterir. Harcanabilecek tutarın Cumhurbaşkanlığ kararnamesiyle aşılabileceğine dair bütçe kanununa hüküm konulamaz." düzenlemesi de eklenebilir. Bu düzenlemede bütçe kanununda harcanabilecek tutarın artırılması konusunda kararname çıkarılması için yetkilendirme yapılamayacağı öngörülerek "kanunla yetkilendirme kuralına istisna getirilmiş" gibi bir anlam belirmektedir6.

Anayasa'nın 8. ve 123/1. maddelerindeki kanunilik ilkesinin eski haliyle korunması ve kararnamelerin kanuna dayanmak zorunda olmadığına dair açık hüküm bulunmaması temelinde, bu görüşün güçlü yönleri bulunsa da kararnamelere ilişkin düzenlemelerin bütünü gözetildiğinde, bu görüşe katılmak mümkün görünmemektedir.

Salih Taşdöğen, ‘Cumhurbaşkanlığı Kararnameleri’ (2016) 65(3) Ankara Üniversitesi Hukuk Fakültesi Dergisi 937, 943; Metin Günday, İdare Hukuku (10. Bası, İmaj 2011) 44, 226-227; K Burak Öztürk, Fransız ve Türk İdare Hukukunda Düzenleme Yetkisinin Kapsamı (Yetkin 2009) 120-122; Lütfi Duran, 'Düzenleme Yetkisi Özerk Sayılabilir mi?' (1983) 4(1-3) İdare Hukuku ve İlimleri Dergisi 33, 38-40.

4 İdarenin düzenleme yetkisinin kapsam ve dayanağı konusundaki içtihat değişikliğine aşağıda değinilecektir.

Turan Yıldırım, ‘Cumhurbaşkanlığı Kararnameleri’ (2017) 23(2) Marmara Üniversitesi Hukuk Fakültesi Hukuk Araştırmaları Dergisi 13, 17-26.

6 Özen Ülgen, 'Cumhurbaşkanlığı Kararnamelerinin Niteliği ve Türleri’ (2018) 1 Galatasaray Üniversitesi Hukuk Fakültesi Dergisi 3, 12 . 
Yıldırım'ın konuları özel olarak Anayasa' da belirlenmiş (md. 104/9, 106/11., 108/4., 118/6., 123/3) olan kararnameler söz konusu olduğunda düzenleme yetkisinin doğrudan Anayasa'nın ilgili maddelerinden kaynaklandığı ve dolayısıyla bunların bir kanuna dayanmak zorunda olmadığına dair görüşüne, herhangi bir karş1 görüş ileri sürülmesi beklenmez. Yazarın bu tespiti, yukarıda zikrettiğimiz, Anayasa değişikliğinden önceki Cumhurbaşkanlığı kararnamesinin kanuna dayanmak zorunda olmadığına dair görüşlerle de uyumludur. Anayasa’nın değişiklikten önceki 107. maddesi, "Cumhurbaşkanlığı Genel Sekreterliğinin kuruluşu, teşkilat ve çalışma esaslarl, personel atama işlemleri Cumhurbaşkanllğı kararnamesi ile düzenlenir." düzenlemesini getirmişti. Bu düzenleme şeklinin değiş̧iklikten sonra getirilen, örneğin Anayasa'nın 108/4. maddesindeki "Devlet Denetleme Kurulunun işleyişi, üyelerinin görev süresi ve diğer özlük işleri, Cumhurbaşkanlı̆̆ kararnamesiyle düzenlenir." düzenlemesinden çok da büyük bir farkı bulunmamaktadır. Esas sorun konusu özel olarak belirlenmiş kararnamelerin değil, genel hüküm niteliğinde olan Anayasa'nın 104/17. maddesinde düzenlenen kararnamelerin bir kanuna dayanmak zorunda olup olmadığ 1 ile ilgilidir.

Öncelikle belirtmek gerekir ki Anayasa idarenin kanuniliği ilkesine paralel bir şekilde kanun hükmünde kararnameler dahil yürütmenin düzenleyici işlemleri ile ilgili hükümlerinde kanun dayanağını ve (tüzükler ile yönetmelikler için) kanuna aykırı olmama ilkesini her zaman açıkça düzenlemiştir. Kararnameler düzenlenirken bu unsurdan bilinçli olarak uzak durulmuştur.

Kararname için bir yetki kanununa ihtiyaç varsa ve kararname kanunla düzenlenmiş konularda çıkarılamayacaksa bu konuda Cumhurbaşkanın takdir yetkisinin bulunduğunu değil, bağlı yetki içinde olduğunu düşünmemiz gerekecektir. Kanunla düzenlenmemiş bir konuda kanunla düzenleme yapma yetkisi vermenin, ifası zorunlu bir görev içerdiği düşünülmelidir?. Oysa, Anayasa'nın 104/17. maddesinin ilk cümlesi Cumhurbaşkanının yürütme yetkisine ilişkin konularda kararname "çıkarabileceği”ni ifade ederek, kullanılması tamamen Cumhurbaşkanının takdirine bırakılmış bir yetkiyi düzenlemiştir. Bu düzenleme açısından Cumhurbaşkanı kanunla düzenlenmemiş bir konuyu kararname ile dilerse düzenler dilerse düzenlemez. Oysa geçmişte, kanun hükmünde kararnamelerin yetki kanununun, yine Anayasa'nın belirlediği özellikleri bakımından Bakanlar Kuruluna kanun hükmünde kararname çıarma konusunda takdir yetkisi sunduğu açıktı. Ayrıca kanun hükmünde kararnamelerin kanunları kaldırma ve bunlarda

\footnotetext{
Aynı yönde bkz. Abdullah Eren, 'Anayasa Mahkemesinin Kanun Hükmünde Kararnamelere İlişsin İçtihadı Doğrultusunda Cumhurbaşkanlığı Kararnamelerinin Değerlendirilmesi' (2019) 36(1) Anayasa Yargısı 1, 68. Elbette muhtemel bir yetki kanununun, düzenleme zorunluluğunu belirginleştiren "kararname ile düzenlenir" ya da takdir yetkisine işaret eden "kararname ile düzenlenebilir" şeklinde farklı ifadeler kullanması mümkündür. Bu ifade farklılıklarının kararname çıkarma zorunluluğu bakımından bir fark yaratmaması gerekir. Zira burada önemli olan Kanun Koyucunun konuyu bir kanunla düzenleme olanağının bulunduğu halde bunu yapmayıp düzenleme görevini yürütmeye vermesi söz konusudur. Kanun koyucu belli bir konuda kararname ile düzenleme yapılması ihtiyacını duymasaydı, buna ilişkin bir yetki kanunu çıkarmazdı. Ayrıca yasama ve yürütme ayrılığının belirginleştiği bir yapıda yetki kanununun yürütmenin talebinden çok yasamanın takdirinde olan bir tercihten kaynaklandığı varsayılmalıdır.
} 
değişiklik yapma gücüne sahip olduğu ve bu gücün kullanılmasının takdir yetkisine dayandığı rahatlıkla ileri sürülebilirdi.

Anayasa'nın 161/7. maddesinde yer alan “Harcanabilecek tutarın Cumhurbaşkanliğ kararnamesiyle aşılabileceğine dair bütçe kanununa hüküm konulamaz." düzenlemesinden kararnamelerin bir yetki kanununa dayanması gerektiği anlamını çıkarmanın mümkün olup olmadığını tartışmak gerekir. Hükümde kast edilenin "Harcanabilecek tutarın aşılabileceğine dair Cumhurbaşkanına bütçe kanunu ile yetki verilemez" olduğu düşünülmelidir. Nitekim, Anayasa'nın 73/4. maddesine göre, "Vergi, resim, harç ve benzeri mali yükümlülüklerin muaflı, istisnalar ve indirimleriyle oranlarına ilişkin hükümlerinde kanunun belirttiği yukarl ve aşağı sınırlar içinde değişiklik yapmak yetkisi Cumhurbaşkanına verilebilir.” Benzer bir yetkilendirme hükmü Anayasa'nın 167/2. maddesinde bulunmaktadır. Bu son iki maddede Cumhurbaşkanına verilen yetkinin kararname ile kullanılacağına dair bir belirleme bulunmamaktadır. Uygulamada da söz konusu yetkiler "Cumhurbaşkanı kararı" şeklinde kullanılmaktadır ${ }^{8}$. Aslında kanunun yetkilendirdiği bir konuda Cumhurbaşkanının "karar" ya da "kararname" adı altında işlem yapması arasında herhangi bir farklılık söz konusu olmayacaktır ${ }^{10}$. Diğer bir deyişle, Anayasa'nın 161/7. maddesinde yer alan "Harcanabilecek tutarın Cumhurbaşkanlığı kararnamesiyle aşılabileceğine dair bütçe kanununa hüküm konulamaz." hükmü, bütçe kanununa harcanabilecek tutarın "Cumhurbaşkanı kararı" ile aşılabileceğine dair hüküm konulabilir şeklinde anlaşılamaz. Ülgen'in de belirttiği gibi Anayasa ile yasaklanan, kanun ile Cumhurbaşkanına yetki verilmesidir ${ }^{11}$. Durum böyle olunca, Anayasa'nın 161/7. maddesindeki "Cumhurbaşkanlığ kararnamesi” ifadesine kanunilik ilkesi ve anayasa sistematiği bakımından özel bir anlam yüklemek mümkün değildir. Sorun, Anayasa değişikliği yapılırken, söz konusu hükümlerde yer alan "Bakanlar Kurulu kararı" ifadesi yerine "Cumhurbaşkanlığı kararnamesi”, "Bakanlar Kuruluna” ifadesi yerine "Cumhurbaşkanına" ifadesinin özensizce yerleştirilmesinden doğmuştur. Eski düzenlemede yer alan "Bakanlar Kuruluna yetki verilmesi” ve "Bakanlar Kurulu kararı" ifadesi herhangi bir sorun doğurmuyordu. Değişiklik metninin, getirilmeye çalışılan kararname rejiminin kendine özgü yönlerinin Anayasa'nın diğer maddelerine olan etkisi düşünülmeden ve bütüncül bir değerlendirme yapılmadan kaleme alınmış olduğu açıktır.

Bkz. 607 sayılı İthalat Rejimi Kararına Ek Karar, RG 15.01.2019/30656.

9 Hukukumuzda "karar" ve "kararname" sözcükleri arasında işlemin niteliğinden kaynaklanan herhangi bir farkl1lı yoktur. Belki, Anayasa değişikliği ve güncel uygulamalar bakımından "Cumhurbaşkanlığı kararı"nın bir kanun ya da kararnameye dayanan işlem olduğu, "Cumhurbaşkanlığı kararnamesi”nin ise herhangi bir dayanağa ihtiyacı olmadığı ileri sürülebilir. Bunun gibi, kavramların öz anlamıyla örtüşmeyen tasnif çabalarının Kanun Koyucunun özensiz ve anlamlandırılması bir hayli güç olan düzenlemelerinden kaynaklandığı düşünülmelidir. Ayrıca bkz. Tolga Şirin, 'İşlemeyen Sistemlerin Fonksiyonel Olmayan Yanıtı: Cumhurbaşkanlığı Kararnamesi' (2018) 7(14) Legal Anayasa Hukuku Dergisi 289, 301-303.

$10 \mathrm{Bu}$ kapsamda kanunun yetkilendirdiği bir konuda kararname adı altında işlem yapılması durumunda işlemin adına değil içeriğine ve niteliğine bakılacaktır. Böyle bir durumda işlemi Anayasa'nın 104/17. maddesi anlamında kararname olarak değil, Cumhurbaşkanının kararname dışında diğer idari işlemi olarak görmek gerekir.

11 Ülgen (dn 6) 13. 
Anayasa'nın TBMM'nin yetkilerini düzenleyen 87. maddesinde "kararnameler için yetki kanunu çıkarmak" şeklinde bir düzenlemenin bulunmaması da kararnamelerin bir yetki kanununa dayanmak zorunda olmadığını göstermektedir. Hatırlanacağı üzere, değişiklikten önce Anayasa'nın TBMM'nin yetkilerini belirleyen 87. maddesinde "Bakanlar Kuruluna belli konularda kanun hükmünde kararname çıkarma yetkisi vermek" şeklinde bir hüküm vardı. Anayasa değişikliği ile Cumhurbaşkanlığ 1 kararnameleri için benzer bir hükmün getirilmemiş olması anlamlıdır. Yine bu açıdan bakıldığında eğer konu yetki kanunu çerçevesinde düşünülseydi kanun hükmünde kararname rejimi bütünüyle kaldırılmazdı. Öyle görünüyor ki Anayasa değişikliği Cumhurbaşkanlığ kararnamelerini normlar hiyerarşisinde kanunların altına yerleştirirken, diğer taraftan da birçok soruna yol açacak şekilde yasama iradesine bağımlılıktan kurtarmıştır ${ }^{12}$.

Özetle, Cumhurbaşkanı kararnamelerinin kanun dayanağına veya TBMM'nin onayına ihtiyacı bulunmamaktadır ${ }^{13}$. Bu düzenleme ile kamu hukuku geleneğimizde köklü yeri bulunan "idarenin kanuniliği" ilkesinde (Anayasa md. 123/1) önemli bir istisna geliştiğini; yürütmenin görev ve yetki olarak nitelendirilmesinde (Anayasa md. 8) "yetki” niteliğinin daha kapsamlı hale geldiğini ileri sürebiliriz.

\section{B. Cumhurbaşkanlığı Kararnamelerinin Normlar Hiyerarşisindeki Yeri}

Cumhurbaşkanlı̆̆ kararnamelerinin tıpkı kanunlar gibi herhangi bir başka norma dayanmak zorunda olmaması; sadece Anayasa' ya uygunluğu açısından ve Anayasa Mahkemesi tarafından denetlenecek olması, bu kararnameleri normlar hiyerarşisinde kanunlarla aynı seviyede görme yanılgısına sebep olabilir. Bu konu ele alınırken öncelikle kararnamelerin bir kamu hukuku işlemi olarak hukuksal niteliğini belirlemek gerekir.

Organik ölçüt bakımından bir işlemin hukuksal niteliğini onu yapan merciin devlet organlarından hangisi olduğuna göre belirleriz. Bu bakımdan Cumhurbaşkanı yürütme organına dahil olduğuna göre, onun kararname adı altında yaptığı işlem "idari işlem" olarak nitelendirilecektir. Kararnamelerin bir kanuna dayanmak zorunda olmaması onları idari işlem olmaktan çıkarmaz. Diğer taraftan, bir işlemin hukuksal niteliğini ve normlar hiyerarşisindeki yerini onun yargısal denetiminin hangi merci tarafindan

\footnotetext{
2 Kanunilik ilkesine getirilen bu istisnanın yol açacağı sorunlara aşağıda değinilecektir.

13 Ali Ulusoy, Yeni Türk İdare Hukuku (Yetkin 2019) 282-283; Oğuz Sancaktar, İdare Hukuku (7. Bası, Seçkin 2018$) 74$.
} 
gerçekleştirildiğine göre belirlemek imkânı yoktur ${ }^{14}$. Bu çerçevede yargısal denetiminin Anayasa Mahkemesi tarafından yapılıyor olması kararnameleri idari işlem olmaktan çıkarmaz ${ }^{15}$.

Atar'a göre, kararnamelerin yargısal denetiminin kanuna değil Anayasa’ya uygunluk denetimiyle sınırlı olması, normlar hiyerarşisinde kararnamelerin kanuna eşdeğer bir norm kategorisi olduğuna işaret eden özelliklerden birisidir ${ }^{16}$. Hemen yukarıda aktardığımız gerekçelerle, yargısal denetimin gösterdiği özellikler herhangi bir normun hiyerarşideki yerini belirlemek adına bizlere çok az veri sunar. Diğer bir deyişle, kanuna dayanmak zorunda olmayan bir yürütme işleminin sadece ve aslında doğal olarak Anayasa'ya uygunluğunun denetlenecek olması o işlemin kanunla aynı güçte bir norm kategorisine dahil olduğu anlamına gelmez. Bu noktada kanuna dayanmak zorunda olmayan yürütme işleminin kanunları değiştirme ve tamamen yürürlükten kaldırma gücüne sahip olup olmadığı belirleyici olacaktır. Bir kanuna dayanmak zorunda olmayan kararnamelerin sadece Anayasa'ya uygunluğunun denetlenebileceği olağan bir sonuçsa; esas önemli olan kararnamenin kanun üzerindeki etki gücüdür ${ }^{17}$.

Bu bağlamda, Anayasa'nın 104/17. maddesinin “Kanunda açıkça düzenlenen konularda Cumhurbaşkanlığı kararnamesi çıkarılamaz." hükmüne göre, kararnamelerin kanunları değiştirme ya da yürürlükten kaldırma gücüne sahip olmadığı açıktır. Aksine, münhasıran kararnamelere ayrılan konular dişında, yine Anayasa'nın 104/17. maddesinin "Türkiye Büyük Millet Meclisinin aynı konuda kanun çıkarması durumunda, Cumhurbaşkanlığı kararnamesi hükümsüz hale gelir." hükmü uyarınca, kanun kararnameyi yürürlükten kaldırma gücüne sahiptir. Ayrıca, "Cumhurbaşkanlı̆̆ kararnamesi ile kanunlarda farklı hükümler bulunması halinde, kanun hükümleri uygulanır." düzenlemesinin kanunun hiyerarşik üstünlüğüne vurgu yapma amaciyla getirildiğini ifade edebiliriz ${ }^{18}$.

\footnotetext{
${ }_{4}$ Yargısal denetimin varlığı ya da yokluğu, hangi yargı merci tarafından gerçekleştirileceği ve usulü, bir hukuksal işlemin niteliği göz önünde bulundurularak kanun koyucu tarafından belirlenecektir. Bununla birlikte yargısal denetime dair özellikleri işlemin hukuksal niteliğini ya da o işlemin normlar hiyerarşisindeki yerini belirlerken ölçüt olarak kullanmak bizleri yanlış sonuçlara götürebilir. Çünkü kanun koyucu işlemin yargısal denetimine dair özellikleri belirlerken çoğu zaman işlemin hukuksal niteliğinden bağımsız ve o işlemin içinde doğduğu hukuksal düzenin gereklerinden farklı düzenlemeler getirebilmektedir. Belli bir idari işlemden doğan uyuşmazlığın, bunu çözecek bir idari yargı düzeni mevcut olduğu halde adli yargı düzeninin görev alanına sokulması bu duruma örnek gösterilebilir. Bu durumda uyuşmazlığın adli yargının görev alanına sokulması, işlemi genetik kodlarından koparıp idari işlem olmaktan çıkarmaz. Yine bir kanun ya da idari işlem yargı denetiminin tamamen dışına çıkarılmış olabilir. Bu durumda kanun ya da idari işlem diğer kanun ya da idari işlemlere göre normlar hiyerarşisinde farklı bir konuma sahip olmayacaktır.

15 Maddi ölçüt bakımından kararnamelerin yasama işlevi içinde görüleceğini ihmal etmemekle birlikte, kararnamelere ilişkin tartışmalarda "idari işlem" niteliğine vurgu yapılması ve zorunlu olmadığı sürece maddi ölçütün kullanılmaması gerektiğini düşünüyoruz. Konunun, geçmişteki kanun hükmünde kararname örneği ile açıklanması için bkz. Eren (dn 7) 17-31.

16 Yavuz Atar, 'Cumhurbaşkanlığı Kararnamelerinin Hukuki Rejimi ve Anayasallık Denetimi’ (2019) 36(1) Anayasa Yargısı $241,243$.

17 Turan Yıldırım, ‘İdarenin Kanuniliği İlkesi Bağlamında Cumhurbaşkanlığı Kararnamelerinin Anayasal Sınırı' (2019) 36(1) Anayasa Yargis1 293, 294.

18 Hükmün bir başka amacının kararnamelerin yargısal denetiminin kanuna uygunluk denetimi değil, sadece Anayasa'ya uygunluk denetimi olduğunu düzenlemek olduğu tespit edilebilir. Bu konuda bkz. Halit Yılmaz, 'Cumhurbaşkanlığı Kararnamelerinin Yargısal Denetimi’ (2019) 7(13) Antalya Bilim Üniversitesi Hukuk Fakültesi Dergisi 373-392.
} 
Ancak hemen yukarıda aktardığımız hükümlerinin basit düzeyde norm çatışma kurallarını düzenlediği ve bu bağlamda norm hiyerarşisi yaratmadığı ileri sürülebilir. Bu görüşe göre, bu düzenlemeler normlar hiyerarşisinde kararnamelerin kanunların altında olduğuna değil; tam tersine onunla denk düzeyde olduğuna işaret etmektedir ${ }^{19}$. Dolayısıyla bu hükümler kararnamenin kanuna aykırı olduğunu ifade etmemizi engelleyerek bu ikisi arasında dikey değil, bunların denkliğine işaret eden yatay bir ilişki kurmaktadır. Norm çatışma kurallarına sadece aynı düzeydeki normlar arasında çatışma olduğunda ihtiyaç duyduğumuza göre, bu görüş ya da yorum ilk bakışta ikna edicidir. Ancak, norm çatışma kuralı Kanun Koyucu tarafından açıkça düzenlendiği için bu görüşe katılmak mümkün değildir. Kanun Koyucu kanun ve kararnameyi normlar hiyerarşisinde eşit düzeyde ve değerde görseydi bunlar arasındaki çelişkiyi giderecek bir düzenlemeye ihtiyaç duymazdı. Zira, birbirine eşit iki norm arasında çelişen hükümler söz konusu olduğunda, konusu bakımından genel norm-özel norm, zaman bakımından önceki norm-sonraki norm ölçütleri sorunu olağan yollardan çözecektir. Diğer bir deyişle, ele aldığımız görüşün tam aksine söz konusu hükümler Anayasa' da hiç bulunmamış olsaydı kanun ve kararnamenin hiyerarşide aynı düzeyde bulunduğunu düşünebilirdik. Zira aynı düzeyde olduğu düşünülen normlar için herhangi bir norm çatışma kuralının işletilmesi bunun açıkça ve ayrıca düzenlenmiş olmasına bağlı değildir. Diğer taraftan, her durumda kanunun uygulanması sonucunu doğuran Anayasa düzenlemesi, eşit düzeydeki normlar arasındaki çatışmayı çözen ve hukuk mantığının olağan ürünü olan diğer bütün çatışma kurallarını bertaraf ettiğine göre artık bir norm denkliğinin kalmadı̆̆ 1 da açıktır.

Anayasa'nın 90. maddesinde yer alan norm çatışma kuralı da bizim yorumumuzu destekleyen tarihsel bir boyuta sahiptir. Anayasa'nın 90. maddesinde 2004 y1lında yapılan değişikliğe kadar uluslararası andlaşmalar kanun hükmünde (kanunla aynı güçte) kabul edildiği için doğal olarak herhangi bir norm çatışma kuralı getirilmemişti. Fakat, daha sonra Kanun Koyucu temel hak ve özgürlüklere dair andlaşmaların kanunların uygulamasını engelleyecek bir üstünlüğe sahip olduğunu vurgulamak için "Usulüne göre yürürlüğe konulmuş temel hak ve özgürlüklere ilişkin milletlerarası andlaşmalarla kanunların aynı konuda farklı hükümler içermesi nedeniyle çıkabilecek uyuşmazlıklarda milletlerarası andlaşma hükümleri esas alınır.” şeklinde bir düzenleme getirmiştir $^{20}$. Bu örnek açısından bakıldığında, yukarıda aktardığımız Anayasa hükümlerinin kararnamelerin kanunlarla eşit bir güçte olmadığını belirlemek amacıyla getirildiği ileri sürülebilir.

Olağanüstü dönemlerde çıkarılacak olan kararnameleri düzenleyen Anayasa'nın 119/6. maddesi, bu kararnamelerin "kanun hükmünde” olduğunu açıkça belirtmiştir. Diğer kararnameler için bu türden açık bir hüküm bulunmadığına göre; sadece

19 Ozan Ergül, 'Yeni Rejimin Kodları: Cumhurbaşkanlığı Kararnameleri’ (2018) Eylül-Ekim Güncel Hukuk 30, 31; Atar (dn 16) 243-244.

20 Eren (dn 7) 28-29. 
olağanüstü hâl kararnamelerinin kanun hükmünde olduğu; diğerlerinin ise olmadığ1 sonucu ortaya çıkmaktadır.

Anayasa'nın "Kanunsuz emir" başlıkl1 137. maddesindeki düzenleme de normlar hiyerarşine uygun bir mantıkla "yönetmelik", "kararname", "kanun" ve "Anayasa" sıralamasını benimsemiştir. Önceki düzenlemede kararname yerine "tüzük" yer almaktaydı. Elbette bu tür bir sıralama kararnamelerin normlar hiyerarşisindeki yerini göstermek bakımından tek başına yeterli değildir. Ancak bu düzenleme şekli Anayasa'nın diğer hükümleri ile birlikte kararnamelerin kanunların altında yer aldığını destekler niteliktedir ${ }^{21}$.

Ülgen'e göre, kararnameler asli bir düzenleme yetkisini ifade ettiğinden kanun gücünde olmasa da kanuna eşdeğer düzenleme araçlarıdır ${ }^{22}$. Gözler, kararnamelerin kanun gücünde olmadığını, artık çıkarılamayacak olan tüzüklere denk olduğunu ifade etmektedir ${ }^{23}$. İster kanunun altında diyelim ister kanuna eşdeğer diyelim, son kertede Anayasa'nın 104/17. maddesinde yer alan kararnamelerin kanunda açıkça düzenlenen konularda çıkarılamayacağı ve aynı konuda kanun çıktığında kararnamenin yürürlükten kalkacağı, kanunla kararname aynı konuda çakıştığında kanunun uygulanacağına ilişkin kurallar kararnamelerin kanun gücünde olmadığını ortaya koymaktadır. Bu hükümlerden kararnamelerin kanunları yürürlükten kaldırma ya da değiştirme gücüne sahip olmadığı sonucu açıkça çıkmaktadır²4.

Önemli bir sorun, Anayasa' da "Cumhurbaşkanlığı kararnamesi ile düzenlenir" şeklinde belirlenen özel konuların (md. 104/9, 106/11, 108/4, 118/6) yürütmenin düzenleme yetkisinin mahfuz alanı olarak nitelendirilmesinin mümkün olup olmadığına ilişkindir. Biz bu konuların sadece kararname ile düzenleneceğini ve bu konularda kanun çıkarılamayacağını düşünüyoruz. Oysa genel hüküm niteliğindeki Anayasa'nın 104/17. maddesine göre, kararname ile düzenlenen yürütme yetkisine ilişkin konularda kanun çıkarılabilecektir. Burada konuları özel olarak belirlenmiş kararnameler ile Anayasa'nın 104/17. maddesinde düzenlenen yürütme yetkisine ilişkin diğer kararnameler şeklinde iki tür kararname bulunup bulunmadığg ve özel konulu kararnamelerin diğer kararnamelerden farklı olarak kanunlarla eşit bir norm seviyede olup olmadığı sorunu ortaya çıkmaktadır. Gerçekten kanuna kapatılmış alanları düzenleyen kararnamelerin kanunlara denk bir güçte olması gerektiği ileri sürülebilir. Ancak, bu kararnameleri bütünüyle Anayasa'nın 104/17. maddesi dışında düşünmek, bu maddede belirginleşen amacın dışında kanuna denk, daha güçlü bir kararname kategorisi oluşturmak anlamına gelecektir. Bu konunun detaylarını aşağıdaki tartışmamızda ele alınmaya çalışacağız.

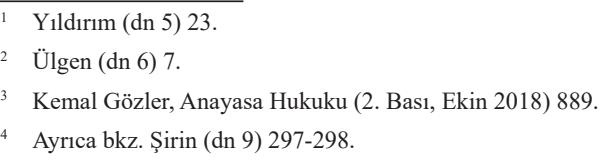


Sonuç olarak, kararnameler asli düzenleme yetkisine dayanmakla birlikte kanun gücünde değildir ${ }^{25}$. Bu sonuç yürütme erkinin kararname yetkisiyle güçlenmesine dair endişelerimizi hafifletmez. Yürütmenin düzenleme yetkisi tali nitelikte ve kanun altı güçte olsa dahi kanun karşısında her zaman genişleme eğilimi gösterir ${ }^{26}$. Mevcut durumda bu eğilimin sinılanması kararname ve kanunun konu bakımından sınırlarının anayasal ölçekte belirginleştirilmesine bağlıdır.

\section{Düzenleme Yetkisinin Yasama ve Yürütme Arasındaki Bölüşümü}

Anayasa'nın 104/17. maddesi kararnamelere ilişkin genel düzenlemeler getirmiştir. Buna ek olarak, Anayasa dört özel konunun kararname ile düzenleneceğini hükme bağlamış bulunmaktadır. Yasama yetkisinin genelliği ilkesi karşısında, özel olarak belirlenen konuların kararnameler için mahfuz bir alan oluşturup oluşturmadığına ilişkin açık bir düzenleme bulunmamaktadır. Anayasa'nın ifade biçimi düzenleme yetkisi bakımından yürütmeye ait mahfuz bir alanın bulunduğunu düşündürmektedir. Konusu özel olarak belirlenmiş kararnamelerin, Anayasa'nın 104/17. maddesindeki genel düzenlemelere tabi olup olmadığı da bir başka tartışma konusudur (A).

Kanunun kararname karşında bir konu sınırlamasına tabi olup olmadığı yanında bir başka sorun kararnamenin kanun karşısındaki sınırlarının neler olduğudur. Kararnameleri konu bakımından sınırlama amacıyla getirilmiş olsa da "münhasıran kanunla düzenlenmesi öngörülen konular" ifadesi kamu hukuku müesseselerimize ve terminolojimize yabancı bir unsur olarak belirmiştir. Zira Türk anayasa hukukunda münhasır kanun alanı bulunmamaktadır (B).

\section{A. Kararname Alanına İlișkin Belirsizlikler}

\section{Yasamanın Genelliği İlkesinde Aşınma: Mahfuz Kararname Alanının Varlığı Sorunu}

Düzenleme yetkisi bakımından yürütmeye ait mahfuz alanın varlığı konusu, yasama yetkisinin genelliği ilkesinin istisnalarının bulunup bulunmadığı ile ilgilidir ${ }^{27}$. Anayasa hukukumuzda yasama yetkisinin genelliği ilkesi esas olmakla birlikte, bu ilke mutlak değildir. Yasama yetkisinin genelliğine dair istisnalar Anayasa'dan kaynaklanmaktadır ${ }^{28}$.

\footnotetext{
Aynı yönde bkz. Sancaktar (dn 13) 81.

26 Yürütmenin başının doğrudan seçimle işbaşına gelmesi ve yasama organına karşı sorumlu olmamasının düzenleme yetkisinin genişleme eğilimini daha da güçlendireceği unutulmamalıdır.

27 Ergun Özbudun, Türk Anayasa Hukuku (17. Bası, Yetkin 2017) 211; Gözler (dn 23) 608-612.

28 Bu istisnalar için bkz. Gözler (dn 23) 608. Yine Özbudun, yasama organının genel olarak statüler yaratmasını yasama yetkinin doğal sonucu olduğunu; ancak, yarattığı statüleri kişiselleştirerek bireysel işlemler yapmasının mümkün olmadığını; bu türden işlemlerin yürütme fonksiyonu kapsamında yer aldığını; yürümenin kural olarak mahfuz ve özerk bir düzenleme yetkisi bulunmamakla birlikte, bireysel işlemler yapmak bakımından mahfuz bir yetki alanı bulunduğunu ifade eder. Özbudun'a göre, aksi bir düsünce kuvvetler ayrılığı ilkesiyle bağdaşmaz. Özbudun (dn 27) 222. Aynı yönde bkz. Gözler (dn 23) 609, 734). Yasama yetkisinin genelliği ilkesi bakımından tespit edilen bu hususların, yürütmenin özerk bir düzenleme yetkisine sahip olmadığı bir durum çerçevesinde, düzenleme yetkisi dıșında kalan konularla ilgili olduğu açıktır. Anayasa değişikliğinin ardından bugün esas sorun, yürütmenin artık özerk bir düzenleme yetkisine sahip olup olmadığıdır
} 
Anayasa'nın 104/17. maddesi yürütme yetkisine ilişkin konularda hem kararname hem de kanun çıkarılabileceğini düzenlediğine ve bu konularda kanunu kararnamelerden daha güçlü kıldığına göre, bu maddeden yasama yetkisinin genelliğine ilişkin bir istisna ortaya çıkmayacaktır. Anayasa'nın kararnameler için belirlediği dört özel konunun ise kanun alanına kapatılıp kapatılmadığı tartışmaya açıktır. Anayasa üst düzey kamu görevlilerinin atanmalarına ilişkin usul ve esasların (md. 104/9); bakanlıkların kurulmaları, kaldırılmaları, teşkilatları ve yetkilerinin (md. 106/11); Devlet Denetleme Kurulunun işleyişi ve üyelerinin statülerinin (md. 108/4); Milli Güvenlik Kurulu Genel Sekreterliğinin teşkilatı ve görevlerinin (md. 118/6) Cumhurbaşkanlığı kararnamesi ile düzenleneceği kuralını getirmiştir.

Özbudun'a göre, bu hükümlerin yürütme organına münhasır bir düzenleme yetkisi verip vermediği açık değildir ${ }^{29}$. Ardıçoğlu'na göre, “...Anayasa değişiklikleri ile yasakoyucuya kapatılmış ve yürütmeye 'münhasır' olarak verilmiş bir düzenleme yetkisinden bahsedebileceğimiz bir anayasa normu yoktur. Bilakis m. 104/17 hükmünde kanuna münhasır alanlar tanınmıştır ve ayrıca aynı konuda Meclis tarafindan kanun çıkarılması durumunda Cumhurbaşkanlığı kararnamesinin hükümsüz hale geleceği düzenlemesine yer verilmiştir. Anayasanın, yasama yetkisin asliliğinin yanı sıra genelliğine ilişkin 7 ve 87'inci maddelerinde kanun koyma, değiştirme ve kaldırma yetkisine ilişkin bir sınırlama da bulunmamaktadır. Kanuna eş bir hukuk kaynă̆ olmayan Cumhurbaşkanliğ l kararnamesinin, kanun önünde bir engel oluşturduğunu kabul etmek sistematik açıdan mümkün görünmemektedir." 30

Gözler, Kanadoğlu ve Ülgen'e göre ise Anayasa'nın özel olarak kararname ile düzenleneceğini belirlediği konularda kanun çıkarılamaz. Zira bu düzenlemelere bakıldığında “Cumhurbaşkanlığı kararnamesiyle düzenlenir" ifadesi, kanun yanında ikinci bir seçeneği değil; tek bir seçeneği ifade etmektedir. Diğer bir deyişle söz konusu ifade biçimi konunun kararname ile düzenlenmesi konusunda sınırlayıcı ve emredici bir niteliğe sahiptir ${ }^{31}$. "Cumhurbaşkanlığı kararnamesiyle düzenlenir” ifadesi açısından yapılan bu yorumu eleştirmek güçtür. Buna ek olarak, kararnamelere ait münhasır alanın varlığına dair görüşün 123/3. maddesinin “Kamu tüzelkişiliği, kanunla veya Cumhurbaşkanlı̆̆ kararnamesiyle kurulur." düzenlemesi açısından da temellendirilmesi mümkündür 123/3. maddesi açısından bakıldığında Anayasa'nın özel olarak kararname ile düzenleneceğini belirlediği konularda kanun çıkarılamayacağı anlamı kendiliğinden belirmektedir. Zira Anayasa'nın bu düzenlemelerinde, 123/3. maddesinden farklı

\footnotetext{
Özbudun (dn 27) 251.

30 Artuk Ardıçoğlu, 'Cumhurbaşkanlığı Kararnamesi' (2017) 3 Ankara Barosu Dergisi 21, 29.

31 Korkut Kanadoğlu, ‘Cumhurbaşkanlığı Kararnamesi’ (2018) 2 Galatasaray Üniversitesi Hukuk Fakültesi Dergisi 637, 645646; Ülgen (dn 6) 19; Gözler (dn 23) 733. Eren’e göre bu yorum münhasır kararname alanının varlığını temellendirmek için yeterli değildir. Nitekim, yazara göre, geçmişte Anayasa Mahkemesinin KHK'lar söz konusu olduğunda Anayasa maddelerinde yer alan "kanunla düzenlenir" ş̧eklindeki ifadeleri "KHK ile düzenlenemez; bu alanlar münhasır kanun alanıdır" şeklinde bir yoruma tabi tutmamıştır. Eren (dn 7) 42-43. Yıldırım ve Atar da Anayasa'da cumhurbaşkanlığ Kararnamesi ile düzenleneceği belirlenen konularda kanunla düzenleme yapılmaması gerektiği görüşüne sahiptir. Yıldırım (dn 17) 300; Atar (dn 16) 247.
} 
olarak, sadece kararname ile düzenleme esası belirlenmiş, kanunla düzenlemeye olanak sağlanmamışıı² ${ }^{32}$ Bütün bunların yanında Anayasa'nın Geçici 21/B maddesine göre "Cumhurbaşkanlı̆̆l kararnamesiyle düzenleneceği belirtilen değişiklikler ise Cumhurbaşkanının göreve başlama tarihinden itibaren en geç altı ay içinde Cumhurbaşkanı tarafindan düzenlenir." hükmünü getirerek kararnamelere ait münhasır alan teyit edilmiş görünmektedir ${ }^{33}$. Katıldığımız bu gerekçelere bir ekleme yapmak faydalı olacaktır. Buna göre, Anayasa'nın belirlediği kararname konularının 104/17. maddesinde belirlenen "yürütme yetkisine ilişkin konular"ın dışında olduğu ileri sürülemez ${ }^{34}$. Bu bakımdan "yürütme yetkisine ilişkin konular"ın kapsayıcıllğ̆ karşısında Kanun Koyucunun bu konuları ayrıca ve özel olarak belirleme amacının mahfuz bir kararname alanı yaratmak olduğunu düşünmek gerekir. Diğer bir deyişle, Anayasa'nın yürütme yetkisine ilişkin konularından dört tanesini somutlaştırma sebebinin bu konuları kanuna kapatmak olduğunu ileri sürebiliriz ${ }^{35}$.

Şirin ise soruna çok daha özgün bir yorum getirmektedir. Yazara göre özel konulu kararnameler münhasır bir konuya sahip değildir. Bu konularda kanun da çıarılabilir. Ancak bu konularda kanunun bulunması kararname çıkarılmasına da engel değildir. $\mathrm{Bu}$ durumda kanun ile kararname arasında çatışma olduğunda kanun uygulanacaktır kuralı geçerli olmayacak, sonraki norm hangisi ise o uygulanacaktır. Şirin'e göre yasama yetkisinin genelliği karşısında münhasır bir kararname alanının varlığından söz edilemez. Yazar ayrıca Anayasa'nın Geçici 21/B maddesinin bu yorumu desteklediği görüşündedir ${ }^{36}$. Sezer ise belirlenen dört özel konuda kararnameden önce kanunla düzenleme yapılamayacağını; kararname ile düzenleme yapıldıktan sonra ise kanun çıkarılabileceği görüşünü paylaşmaktadır ${ }^{37}$.

Kural olan yasama yetkisinin genelliği ilkesi ise bunun istisnasının Anayasa'da açık bir şekilde belirlenmesi gerekliliğinden vazgeçemeyiz. Bu bakımdan kararnamelerin düzenlediği belli konularda kanun çıkarılamayacağına dair daha açık bir hükme gerek olduğunu, eğer düzenlemelerin amacı tam olarak bu ise açıklığın yeterince sağlanamamış olduğunu kabul ediyoruz. Ancak yukarıda yaptığımız açıklamalar istisnanın belirgin olma özelliğinden yoksun olmadığını da göstermektedir.

\footnotetext{
Gözler (dn 23) 733.

Eren (dn 7) 43; Ülgen (dn 6) 19-20.

34 Abdullah Sezer, 'Normlar Hiyerarşisi ve Cumhurbaşkanlığı Kararnameleri [Çok Boyutlu Normlar Piramidi Yaklaşımı]' (2019) 36(1) Anayasa Yargısı 353, 371. Yürütme yetkisine ilişkin konuları genel olarak belirleme güçlüğünü aşağıda açıklamaya çalışacağız. Kanun Koyucunun özel konulu kararnameleri Anayasa'da düzenlemesi bu güçlüğün aşılması için örnek olarak değerlendirilebilir.

35 Melikşah Yasin, 'Cumhurbaşkanlığı Kararnamelerinin Türk İdari Teşkilat Hukukuna Etkileri' (2019) 36(1) Anayasa Yargısı 315,318 .

36 Yazar bu konuda başka gerekçeler de sunmaktadır. Bkz. Şirin (dn 9) 331-335.

37 Sezer (dn 34) 377-388.
} 
Anayasa’nın 104/17. maddesinde düzenlenen kararnamelerin kanunlarla aynı güçte olmadığını belirlemiştik. Hemen aşağıda inceleyeceğimiz üzere, Anayasa'da konusu özel olarak belirlenmiş olan kararnameler de Anayasa'nın 104/17. maddesinden ayrı bir kategori olmadığına göre, bunlar da kanunlarla aynı güçte değildir. Şimdi bu tartışma çerçevesinde "Kanuna denk olmayan kararnamelere" mahfuz bir alan yaratılmış olmasının mümkün olup olmadığı sorununu ele almak gerekir. Gerçekten mahfuz bir kararname alanı varsa mahfuz konulardaki kararnamelerin, Anayasa'nın 104/17. maddesindeki kararnamelerden farklı olarak kanun gücünde olması gerektiği düşünülebilir ${ }^{38}$. Bu sorun bakımından tartışma konusu hükümlerin üç farklı yorumla ele alınması mümkün görünüyor: 1) Anayasa' da mahfuz alan konusunda açık düzenleme bulunmamaktadır. Dolayısıyla kanuna denk olmayan kararnamelerin mahfuz bir alana sahip olması düşünülemez. 2) Mahfuz alanın varlığı Anayasa'nın yorumundan çıkmaktadır. Dolayısıyla özel konulu kararnameler diğerlerinden farklı olarak kanun gücündedir. 3) Mahfuz alanın varlığg Anayasa'nın yorumundan çıkmaktadır. Mahfuz alanın varlığı ile bu alanda çıkarılacak kararnamelerin normlar hiyerarşisindeki yeri farklı tartışma konularıdır. Bu kararnameler kanun gücünde değildir ve diğer kararnamelerle aynı statüdedir.

Bize göre uygun yorum üçüncü seçenektir. Belli bir alanın kanun düzenlemesine kapatılması, o alanı düzenleyen normu kanun gücünde görmemizi zorunlu k1lmayabilir ${ }^{39}$. Kanunların bu kararnameleri değiştirip yürürlükten kaldıramamasının sebebi bunların kanunlarla aynı güçte ya da daha güçlü olmalarından değil, Anayasa ile mahfuz bir alan yaratılmış olmasından kaynaklanmaktadır. Belli bir alanın kanun düzenlemesine kapatılmış olması ile o alanı düzenleyen normun normlar hiyerarşisindeki yerine dair konular birbiriyle ilişkili olsa da sıkı sıkıya bağlı olmayabilir. Bu açıdan mahfuz düzenleme konularına sahip kararnameler kanunla aynı güçte olmayabilir. Kanunun özel konulu kararnameleri kaldıramaması ve değiştirememesi, hiyerarşideki norm konumlanışıyla ilgili bir konu olmak zorunda değildir ${ }^{40}$. Aksini düşünecek olursak, özel konulu kararnamelerin kanun tarafından kaldırılıp değiştirilememesi, bizi bu kararnamelerin kanunlardan daha üstün olduğu sonucuna da görebilir.

Bu konuda son olarak Anayasa’nın mülga 107. maddesinde düzenlenmiş, konusu Cumhurbaşkanlığı Genel Sekreterliği ile sınırlı Cumhurbaşkanı kararnamesine ilişkin görüşlere de yer vermek gerekir. Geçmişte, mülga 107. maddedeki düzenlemenin, Cumhurbaşkanına mahfuz bir alanda düzenleme yetkisi verdiği görüşü savunulmuştu ${ }^{41}$.

\footnotetext{
Yasin Söyler, Yeni Başkanlık Sisteminde Cumhurbaşkanlığı Kararnamesi (Seçkin 2018) 166. Şirin'e göre “Cumhurbaşkanlığı kararnamesinin özerk alanı olduğunu söylemek, bu normun söz konusu alanlarda kanun hükmünde olduğunu söylemek anlamına gelir." Yazara göre bu kararnamelerin kanun gücünde olmadığını kabul etmek gerekir. Fakat yazar özel konulu kararnamelerin aynı konuyu düzenleyen kanun bulunsa bile çıkarılabileceğini ve o andan sonra da artık kanunun uygulanmayacağını (aslında kararnamenin kanunu yürürlükten kaldıracağını) ifade etmektedir. Şirin (dn 9) 331, 334. Oysa bu yorumun, konusu özel olarak belirlenmiş kararnameleri kanun gücünde görmek dışında bir anlamı bulunmamaktadır.

39 Aynı yönde bkz. Eren (dn 7) 29-30.

40 Bu konuya aşağıda değineceğiz.

41 Özbudun (dn 27) 217; Taşdöğen (dn 3) 943; Öztürk (dn 3) 122-123.
} 
Bununla birlikte, mülga 107. maddede düzenleme konusunun sınırları belirlenmiş olduğu için bunların dışındaki konular, Cumhurbaşkanlığı Genel Sekreterliği konulu Cumhurbaşkanlığ kararnamesi yanında, ayrıca mülga 2879 sayılı Cumhurbaşkanlığ1 Genel Sekreterliği Teşkilatı Kanunu ile düzenlenmişti. Bu Kanun'un 1. maddesi kapsamını "Bu Kanun; Cumhurbaşkanlığ kararnamesi ile düzenlenen Cumhurbaşkanlığı Genel Sekreterliğinin kuruluşu teşkilatı, çalışma esasları ve personel atama işlemleri dışında kalan konuları düzenler." şeklinde belirlenmişti. Dolayısıyla yasama organı da mahfuz bir kararname alanının varlığını kabul etmişti. Öztürk, bu Kanun'un bazı düzenlemelerinin kararname alanına sirayet ettiğini ve bu nedenle de Anayasa'ya aykırılık taşıdığını tespit etmiştir ${ }^{42}$. Geçmişte yapılan bu yorumların ele aldığımız Anayasa değişiklikleri bakımından da geçerli olmaması için bir sebep yoktur.

Özetle, yürütmenin özerk düzenleme yetkisine bağl1 olarak, "yetki” niteliğinin daha da belirginleştiği; Anayasa'nın 123/3. maddesinde kanun ve kararname seçeneklerinin birlikte öngörüldüğü; yine özel olarak belirlenen konularda "Cumhurbaşkanlığ1 kararnamesiyle düzenlenir" ifadesinin kesin ve emredici niteliği gözetildiğinde, Anayasa'nın 104/9, 106/11., 108/4., 118/6. maddeleriyle belirlenen konularda kanun çıkarılması mümkün görünmemektedir. Bu sonucu destekleyen saydığımız unsurların tutarlı bütünlüğü karşısında, Anayasa'da açıkça "Cumhurbaşkanlığı kararnamesi ile düzenleneceği özel olarak belirlenmiş konularda kanun çıkarılamaz" şeklinde bir hükmün bulunmadığına yönelik haklı bir itiraz ${ }^{43}$; ulaştığımız sonuç hakkında bizi yeniden düşünmeye sevk etse de bu sonuçtan vazgeçmemiz için yeterli olmayacaktır. $\mathrm{Bu}$ konuda tereddütleri giderecek Anayasa hükmünün bulunmaması, eleştirilmesi gereken bir eksikliktir.

\section{Mahfuz Konulu Kararnamelerin Genel Sinırlamalara Tabi Olması Sorunu}

Mahfuz kararname alanının mevcudiyetine dair açık olmasa da güçlü bir anlama sahip Anayasa değiş̧ikliğinin yarattığı önemli açmazlardan birisi, bu kararnamelerin Anayasa'nın 104/17. maddesinde düzenlenen kararnamelerden farklı olup olmadığına ilişsindir.

Konuyu bu kararnameleri Anayasa'nın 104/17. maddesindeki kararnamelerden ayrı bir yere koymamızı gerektirecek sebeplerin varlığını tartışarak ele almak gerekir. Öncelikle, Anayasa'nın bu kararnamelerin konularını belirlerken bunları diğer kararnamelerden ayrı bir şekilde değerlendirmemizi gerektirecek yoruma elverişli herhangi bir düzenleme getirmemiş olduğunu belirtmek gerekir ${ }^{44}$. Diğer yandan,

\footnotetext{
42 Öztürk (dn 3) 122-123. Ayrıca bkz. Ülgen (dn 6) 24.

43 "Kanunda açıkça düzenlenen konularda Cumhurbaşkanlığı kararnamesi çıkarılamaz." "Anayasada münhasıran kanunla düzenlenmesi öngörülen konularda Cumhurbaşkanlı̆̆ı kararnamesi çıkarılamaz." hükümleri Anayasa'nın 104/17. maddesinde mevcutken, bu itiraz yersiz ya da cılız bir itiraz değildir. Örneğin bkz. Şirin (dn 9) 332.

44 Yorum tekniği açısından daha detaylı bir açıklama için bkz. Yıldırım (dn 17) 311-314.
} 
yukarıda da ifade ettiğimiz gibi Anayasa'nın belirlediği kararname konularının 104/17. maddesinde belirlenen "yürütme yetkisine ilişkin konular"1n dişında olduğu ileri sürülemez. $\mathrm{Bu}$ açıdan bakıldığında, bu kararnameleri, diğer kararnameler için oluşturulan hukuksal rejimden ayrı tutmak hukuksal rejim açısından istisna oluşturmak anlamına gelir. Eğer bu kararnameler Anayasa'nın 104/7. maddesindeki hukuksal rejimden istisna edilecek olursa, olağanüstü hâl kararnameleri ve yürütme yetkisine ilişkin konulardaki kararnameler şeklinde hukuksal rejimi belli iki kararname türü yanında, belirgin bir hukuksal rejimi bulunmayan özel konulu kararnameler ortaya çıkmış olacaktır.

Eğer özel konulu kararnamelerin hukuksal rejiminin ayrı bir özelliği yoksa, Anayasa'nın 104/17. maddesinde kararnameler için getirilen sınırlandırıcı hükümlerin tamamının, konuları özel olarak belirlenmiş kararnameler için geçerli olup olmadığının daha somut bir şekilde açıklanması gerekir.

$\mathrm{Bu}$ sinırlamalardan birincisi "Anayasanın ikinci kısmının birinci ve ikinci bölümlerinde yer alan temel haklar, kişi haklarl ve ödevleriyle dördüncü bölümde yer alan siyasi haklar ve ödevler Cumhurbaşkanlı̆̆l kararnamesiyle düzenlenemez" sınırlamasıdır. Aynı maddede yer alan sınırlandırmalardan bir başkası Anayasa'da münhasıran kanunla düzenlenmesi öngörülen konuların kararname ile düzenlenemeyeceğine ilişkindir. Anayasa’nın 13. maddesinin “ancak kanunla sınırlandırılabilir" hükmünü karşısında herhangi bir kararnamenin temel hak ve özgürlükler kategorilerinde sınırlandırıcı bir düzenleme getirmesinin mümkün olamayacağ1 ileri sürülebilirse de ${ }^{45}$ bu kararnameleri Anayasa'nın 104/17. maddesindeki sınırlamalar dışında düşünecek olursak özel konulu kararnameleri Anayasa’nın 13. maddesinin temel hak ve özgürlüklerin "ancak kanunla sınırlandırılacağı” kuralı ile de sınırlama olanağını yitirme tehlikesi ile karşılaşılabilir. Söyle ki, bilindiği üzere Anayasa'nın 13. maddesi “ancak kanunla sınırlanabilir” ifadesini kullanmakta, 104/17. maddesi ise "Cumhurbaşkanlığ kararnamesiyle düzenlenemez" ifadesini kullanmaktadır. Bu iki farklı ifade biçimi karşısında konusu özel olarak belirlenmiş kararnameleri Anayasa’nın 104/17. maddesinin kapsamı dışında görmenin beraberinde getireceği bir sorunun ele alınması gerekir. Eğer sınırlama ve düzenleme kavramları konusunda bir anlam farkı gözetilecek olursa ${ }^{46}$, Anayasa’nın 104/17. maddesinin “düzenlenemez" ifadesi "sınırlama içermese bile düzenlenemez"; "her ne olursa olsun

\footnotetext{
45 Ülgen (dn 6) 22. Yazar, özel konulu kararnameleri Anayasa'nın 104/17. maddesindeki hukuksal rejimin dışına çıkarırken tehlikenin farkındadır ve temel hak ve özgürlüklerin kanun güvencesinden yoksun kalmadığını ifade etmek için 13 . maddenin her durumda kararnameler için engelleyici bir anlama sahip olduğunu ileri sürmektedir.

46 Türk kamu hukuku öğretisinde temel hak ve özgürlükler bağlamında "sınırlandırma" ve "düzenleme" kavramını sistematik bir şekilde ele alan ilk eser Sağlam’a aittir. Yazara göre, “...temel hak ve özgürlüklere yönelik her yasal düzenleme sinırlama kavramı ile özdes değildir. Bir sınırlamanın söz konusu olup olmadığını saptavabilmek için, yapılan düzenlemenin içeriğine bakmak gerekir. Bu düzenleme, belli bir temel hak ve özgürlügün güvence altına aldığl yaşam kesitini, daha yeni bir terimle 'norm alanını' daraltma sonucunu doğuruyorsa, bu bir sinırlamadır. Buna karşıllk temel hakkı güçlendirici, onun daha kolay ve etkin bir biçimde kullanılmasını sağlayıcı düzenlemeler sınırlama değildir." Fazıl Sağlam, Temel Hak ve Hürriyetlerin Sınırlanması ve Özü (AÜSBF 1982) 21.
} 
kararnameler belirlenen temel hak ve özgürlükler kategorisini konu edinemez" şeklinde anlaşılır. Konusu özel olarak belirlenmiş kararnameleri Anayasa'nın 104/17. maddesi kapsamında görmeyen bir yorum, bu kararnameler temel hak ve özgürlükler kategorisini konu edindiğinde bu konunun sınırlama içermediğini; sınırlamanın kanunla olabileceğini, oysa kararnamenin sınırlama değil "düzenleme" içermekte olduğunu ileri sürebilir. Sınırlama ve düzenleme kavramlarının karşılıklı olarak her durumda sınırları belirgin kavramlar olamayacağı düşünüldüğünde kararnamelerin temel hak ve özgürlükleri konu edinme tehlikesi açıktır. Özellikle Anayasa'nın 106/11. maddesinde bakanlıkların "yetkileri”nin de kararname ile düzenleneceği öngörüldüğüne göre açıklamaya çalıştığımız türden bir sonuç muhtemeldir ${ }^{47}$. Kararnameler dışındaki diğer düzenleyici işlemler bakımından da benzer bir durumun söz konusu olduğu; münhasır kanun alanı bulunmadığı için kanunla sınırlanan temel hak ve özgürlükler alanının düzenleyici işlemlerle düzenlenebileceği ileri sürülebilir. Ancak burada esas sorun kararnamelerin diğer düzenleyici işlemlerden farklı olarak bir kanuna dayanmak zorunda olmamasıdır. Bu özelliği nedeniyle özel konulu kararnamelere, "düzenleme" niteliği varsayılarak temel hak ve özgürlükleri konu edinme olanağ 1 kesinlikle yaratılmamalıdır. Bunun için bu kararnameleri Anayasa'nın 104/17. maddesinin "düzenleme yasağı"nın dışında ayrı bir kategori olarak değerlendirmemek gerekir.

Burada, konusu özel olarak belirlenen kararnamelerin o konuyu düzenlerken temel ve özgürlükler alanına ilişkin sınırlamalar getirmesi ihtimalini değerlendirmeye devam etmeden önde bir istisnadan söz etmek ve konuya buradan devam etmek uygun olacaktır. Bilindiği üzere Anayasa'nın “Siyasi Haklar ve Ödevler Bölümü”nde yer alan "kamu hizmetine girme hakkı" 70. maddede düzenlenmiştir. Yukarıdaki açıklamalarımız çerçevesinde, kararnamelerin bu hakkı sınırlandırıcı bir hüküm getirmesi mümkün olmadığg gibi "düzenlemesi” de mümkün görünmemektedir. Bu hem hakkın Anayasa'da yer aldığı bölümün kararnameler için yasak alan olarak belirlenmesinin bir sonucudur hem de Anayasa'nın 128/3. maddesindeki "Memurlarm ve diğer kamu görevlilerinin nitelikleri, atanmalarl, görev ve yetkileri, haklarl ve yükümlülükleri, ayllk ve ödenekleri ve diğer özlük işleri kanunla düzenlenir." hükmünün bir sonucudur. Oysa Anayasa'nın 104/9. maddesi Cumhurbaşkanın yetkilerini düzenlerken "Üst kademe kamu yöneticilerini atar, görevlerine son verir ve bunların atanmalarına ilişkin usul ve esasları Cumhurbaşkanlığı kararnamesiyle düzenler." hükmünü getirmiştir. O halde konu üst kademe yöneticileri olduğunda, kararname için getirilen "Siyasi Haklar ve Ödevler Bölümünde yer alan haklar kararname ile düzenlenemez" yasağ geçerli olmayacaktır.

Fakat burada "üst kademe yöneticileri" ile ilgili özel bir istisnanın, istisna olmanın özelliğine uygun olarak açıkça belirtildiğine vurgu yapmak gerekir. Çünkü bu noktada tekrar şu soru akla gelecektir: “Anayasanın 106. maddesi gereğince bakanlı kuran 
Cumhurbaşkanlı̆̆ı kararnamesi, Anayasanın 104. maddesinin 17. fikrasindaki sinırlara tabi olmayacak mıdır? Örneğgin İ̧̧işleri Bakanlı̆̆ına Anayasanın 13. maddesine aykırı şekilde, kanun olmaksızın, kişi hürriyetini sinırlama yetkisi verilebilecek midir?" "48 Yıldırım'a göre, “Anayasanın 106. maddesinin, özel hüküm olduğu gerekçesiyle, Anayasanın ilgili maddeleri ile 13. maddesi ve 104/17. maddesiyle bağl olmaksızın, Cumhurbaşkanlı̆̆ kararnamesi çıkarma yetkisi verdiği şeklinde bir yorum yapılamaz." ${ }^{\prime \prime 9}$ Gerçekten bir işlemin konusunun özel olarak belirlenmiş olması, sadece bu sebeple o işlemin genel hükümlerle belirlenen sınırlamalardan istisna edildiği anlamına gelmeyecektir. Oysa Eren'e göre özel olarak kararnamelerin düzenlemesine bırakılmış olan konularda kanun çıkarılamaz; bu alanlar tamamen yürütmenin düzenleme yetkisine ayrılmıştır; "Böylece 13. maddedeki 'kanunla sınırlama'ilkesi bakımından, münhasır CBK ile düzenlenecek alanlar istisna haline gelmiştir. Kanunla sınırlama dışında, 13. maddedeki sınırlamanın sinırını oluşturan güvenceler uygulanmaya devam edecektir. Aksi yorumun benimsenmesi halinde, münhasır CBK alanında, sinırlamaların ayrıca kanunla yapılabileceği gibi tutarsı bir sonuca ulaşıllır. Her sinırlamanın aynı zamanda bir düzenleme olduğunu kabul ettiğimizde, kanunla bu alanda sinırlamaların ayrıca yapılacağını söylemek münhasır CBK alanını savunan görüşler bakımından tutarsızlı olacaktır." ${ }^{50} \mathrm{Bu}$ görüşün, münhasır kararname alanı olarak gördüğü konularda kanunun hiçbir temas noktası oluşturamayacağı gibi eleştiriye açık bir kavrayışa sahip olduğu anlaşılıyor. Bir temel hak ve özgürlüğün sınırlandırılması sınırlandırmanın icrası bakımından yürütme organına bir kısım yetkilerin verilmesini gerektirebilir. Böylece sınırlandırma ve yetkilendirme ayrılmaz bir birliktelik gösterebilir. Bu bakımdan örneğin Kanun Koyucunun bir sınırlandırma yaparken sınırlandırmanın icrası bakımından örneğin İçişleri Bakanlığını yetkilendirmesi, kararnameye hasredilmiş bir alana kanunla girildiği anlamına gelmeyecektir ${ }^{51}$. Eğer temel hak ve özgürlükler ancak kanunla sınırlanabilecekse, bu yetki sınırlamanın icrası konusunda hangi idarenin yetkili olduğunu ve bu yetkinin kullanılma usulünü belirleme yetkisini de doğal olarak içerir. Bu noktada kararnamelere hasredilmiş alanların varlığ 1 ile temel hak ve özgürlüklerin kanunla sınırlandırılması noktasında yapılan idari yetkilendirmeler arasında bir tutarsızlık ya da çelişki bulunmamaktadır. Bu sadece temel hak ve özgürlüklerin sınırlandırılması bakımından değil; kanun koyucunun düzenlediği herhangi bir konu bakımından da mümkündür. Kanun koyucunun düzenlediği herhangi bir kamu hizmetini bir bakanlıkla ilişkilendiremeyeceğini; çünkü bakanlıkların görev

51 Yasin, 1 No'lu Cumhurbaşkanlığı Teşkilatı Hakkında Cumhurbaşkanlığı Kararnamesi’nin İçişleri Bakanlığının görev ve yetkilerini düzenleyen 254. maddesinde sıralanan "yurdun iç güvenliğini ve asayişini, kamu düzenini ve genel ahlak1, Anayasada yazılı hak ve hürriyetleri korumak"; "Sınır, kıyı ve karasularımızın muhafaza ve emniyetini sağlamak"; "karayollarında trafik düzenini sağlamak ve denetlemek", "suç işlenmesini önlemek", "suçluları takip etmek ve yakalamak", "her türlü kaçakçılığı men ve takip etmek" gibi görev ve yetkilerin temel hak ve özgürlüklerin sınırlandırılması sonucunu doğuracağını ileri sürmektedir. Yasin (dn 35) 324. İlk bakışta bu endişe haklı gibi görünse de bu yetkilerin kullanılması şart ve usullerinin tamamının kanunla düzenlendiği; kanun bulunmadığı sürece bu son derece genel ifadelerle belirlenmiş yetkilerin kullanılmasının mümkün olamayacağının altını çizmek gerekir.
} 
ve yetkilerinin ancak kararname ile düzenlenebileceğini ileri sürmek mümkün olmasa gerekir. Yine kanun koyucunun belli bir konuyu düzenledikten sonra ayrıntıların, örneğin İçişleri Bakanlığı tarafından düzenleneceği şeklinde bir düzenleme yetirmiş olması, diğer bir deyişle yönetmelik çıkarma konusunda İçişleri Bakanlığını yetkilendirmiş olması mahfuz kararname alanına girdiği şeklinde yorumlanmamalıdır. Örneğin Belediye Kanunu'nun 10. maddesinde yer alan “Bir beldenin adl, belediye meclisi üye tam saylsının en az dörtte üç çoğunluğunun kararı ve valinin görüşü üzerine İ̧̧işleri Bakanlığının onayı ile değiştirilitr." hükmü İçişleri Bakanlığına vesayet yetkisi verirken mahfuz kararname alanına mı girmiş̧tir? Buna benzer yüzlerce örnek verilebilir. Tekrar etmek gerekirse, mahfuz kararname alanı niteliği, Kanun Koyucunun düzenlediği konularla bu kararname alanlarıyla hiçbir ilişki kurmayacağı şeklinde anlaşılmamalıdır. O halde mahfuz kararname alanının ne anlama geldiği bu kapsamda daha somut bir şekilde belirginleştirilmelidir. Yine bakanlıklar üzerinden açıklayacak olursak, kanun bakanlıkların teşkilatını, bu teşkilat yapısına bağlı görev ve yetkileri; daha genel düzeyde bakanlığın faaliyet alanını ve bu alanla ilgili sahip olduğu genel yetkileri "kurucu nitelikte" düzenleyemez. Ülgen, bu konuyu bir başka açıdan şu şekilde ifade etmektedir: "Tarihsel gelişim ve Anayasa'nın sistematik yorumu dikkate alındı̆̆ında, Bakanlıkların görev ve yetkisinin belirlenmesinin kendi aralarındaki görev ve yetki paylaşımının belirlenmesi olarak anlaşılması gerekir. Bu yorum kanunla bakanlıklara başka görev ve yetkiler verilmesine engel olmayacaktır." 52

Bu açıdan bakıldığında kararname ile düzenleme yapılırken Anayasa'nın 104/17. ve 13. maddesi çerçevesinde bakanlıkların yetkilerinin temel hak ve özgürlüklerin sınırlandırılması sonucunu doğuracak bir nitelik taşımaması gerekir. Konusu özel olarak belirlenmiş kararnameleri Anayasa'nın 104/17. maddesi dişında tutmak kararname yetkisini Anayasa'nın 13. maddesindeki "ancak kanunla sınırlanabilir" şartından istisna etmeye varacak uç yorumlara yol açabilir ve yargı organının yetkili olduğu konular dışında kalan hemen hemen bütün temel hak ve özgürlüklerin bakanlıkların görev ve yetkilerinin belirlenmesi amacı altında kararname ile sınırlandırılması olanağı gelişebilir. Ayrıca, tam da bu sebeple konusu özel olarak belirlenmiş olan kararnamelerin "kanun gücünde" olduğuna dair yorumlara ${ }^{53}$ temkinli bir şekilde yaklaşmak gerekir. Anayasa'nın temel hak ve özgürlükler rejiminin 2017 Anayasa değişikliğinden sonra geçmişe göre farklı bir açıdan değerlendirilmesini gerektirecek hiçbir sebep bulunmamaktadır. Esas olan kararnamelerin değil temel hak ve özgürlüklerin hukuksal rejimidir.

\footnotetext{
22 Ülgen (dn 6) 22. Ülgen bir başka yerde aynı sorunu temel hak ve özgürlüklerin sınırlandırılması bağlamında Kanun Hükmünde Kararname uygulaması örnekleriyle daha detaylı bir şekilde açıklamaktadır. Bkz. Özen Ülgen, 'Kanun-Cumhurbaşkanlığı Kararnamesi İlişkisinin Yargısal Denetimine Yönelik Sorunlar' (2019) 36(1) Anayasa Yargısı 261, 273-274.

53 Bu yönde bir yorum için bkz. Hasan Tunç, Türk Anayasa Hukuku (Gazi 2018) 234.
} 
Anayasa'nın 104/17. maddesinde yer alan ikinci sınırlama “Anayasada münhasıran kanunla düzenlenmesi öngörülen konularda Cumhurbaşkanlığ kararnamesi çıkarılamaz." hükmüdür ${ }^{54}$. Bu sınırlama özel konulu kararnameler için de geçerli olmalıdır. Çünkü Anayasa'da belirlenen sınırlı konularda çıkarılan kararnamelerin sınırlarını aşıp Anayasa'nın kanunla düzenlenmesini emrettiği konuları da kapsamına alması ihtimal dahilindedir. Kanunla düzenlenmesi gereken veya kanunda açıkça düzenlenen konular sınırı çoğu zaman belirgin olmayabilir. Bu konuda bazı örnekler üzerinde durulabilir. Anayasa'nın özel olarak belirdiklerinin arasında en geniş düzenleme konusu "Bakanlıkların kurulması, kaldırılması, görevleri ve yetkileri, teşkilat yapısı ile merkez ve taşra teşkilatlarının kurulması Cumhurbaşkanlığ kararnamesiyle düzenlenir." hükmüyle 106/11. maddesinde yer almıştır. Buna karşın diğer üç konuda düzenleme sahası o kadar geniş tutulmamıştır. Örneğin, Anayasa'nın 104/9. maddesine göre, Cumhurbaşkanı "Üst kademe kamu yöneticilerini atar, görevlerine son verir ve bunların atanmalarına ilişkin usul ve esasları Cumhurbaşkanlı̆̆ kararnamesiyle düzenler." Yine Anayasa'nın 128/3. maddesine göre, “Üst kademe yöneticilerinin yetiştirilme usul ve esasları, kanunla özel olarak düzenlenir.” O halde üst kademe yöneticilerine ilişkin bütün konular kanun konusu olmaktan çıkmamıştır ve dolayısıyla kararname konuyu her yönüyle düzenleyemez. Benzer bir durum Milli Güvenlik Kuruluna ilişkin kararnameler için de geçerli olacaktır. Anayasa'nın 118/6. maddesine göre, "Milli Güvenlik Kurulu Genel Sekreterliğinin teşkilatı ve görevleri Cumhurbaşkanlığı kararnamesiyle düzenlenir.” Ancak kararname Milli Güvenlik Kurulu Genel Sekreterliğinde istihdam edilecek kamu görevlileri ile ilgili özel düzenlemeler getiremez. Zira Anayasa'nın 128/2. maddesine göre kamu görevlilerine ilişkin düzenlemelerin kanunla yapılması gerekir. Daha somut bir örnek olarak, Anayasa'nın “Devlet Denetleme Kurulu” başl1kl1 108/4. maddesinin “Devlet Denetleme Kurulunun işleyişi, üyelerinin görev süresi ve diğer özlük işleri, Cumhurbaşkanliğ kararnamesiyle düzenlenir." hükmü ve buna istinaden çıkarılan 5 sayılı Cumhurbaşkanlığı Kararnamesi'nin ${ }^{55}$ 6. maddesi üzerinde durulabilir. Kararname'nin 6. maddesi denetleme (ve soruşturma) sırasında kamu görevlisini görevden uzaklaştırma yetkisini düzenlemiştir. Oysa görevden uzaklaştırma kamu görevlisinin statüsünde geçici de olsa bir k1sıtlama getirir ve Anayasa'nın 128/2. maddesi gereği bu konunun kanunla düzenlenebilecek bir konu olduğu ileri sürülebilir. Görevden uzaklaştırma yetkisinin kamu görevlilerinin statüsüne ilişkin özel bağlamı bir tarafa, aynı Kararname'nin Devlet Denetleme Kurulunun diğer “yetki”lerini düzenlediği 5. maddesi de tartışmaya açıktır. Zira, Anayasa'nın 108/4. maddesi Devlet Denetleme Kurulunun “yetki”lerinin de düzenleneceğine dair bir unsuru içermemektedir ${ }^{56}$. Nitekim Anayasa'nın bakanlıklara ilişkin 106/11. maddesi bakanlıkların “yetki”lerinin de kararname ile düzenleneceğine

\footnotetext{
54 Aşağıda açıklayacağımız üzere, "münhasıran kanunla düzenlenmesi öngörülen konular” ifadesinin, "kanunla düzenlenmesi öngörülen konular" şeklinde anlaşılması gerekir.

55 RG 15.07.2018/30479.

56 Ülgen de bu konuda kanun çıkarılması gereğini ifade etmiştir. Ülgen (dn 6) 25.
} 
dair açık bir hükme sahiptir. Anayasa'nın 123/1. maddesine göre idare kuruluş ve görevleri ile "kanunla" düzenlenecekse, Devlet Denetleme Kurulunun yetkilerinin kanunla düzenlenmesi gerektiği ileri sürülebilir. Bunula birlikte Devlet Denetleme Kurulunun yetkilerinin kararname ile düzenlenip düzenlenmeyeceği meselesinin Anayasa'nın 104/17. maddesinde belirlenen "yürütme yetkisine ilişki konular" çerçevesinde tartışmaya açık olduğu ve kanunla düzenlenmediği sürece kararname ile düzenlenebileceği de ileri sürülebilir. Bu son görüşün benimsenmesi Devlet Denetleme Kurulunu düzenleyen kararnamenin "münhasıran kanunla düzenlenmesi emredilen konularda kararname çıkarılamaz" kuralından istisna edildiği anlamına gelmeyecektir. Özetle, Anayasa'da kanunla düzenlenmesi emredilen konularda kararname çıkarılamayacağına dair kısıtlamanın, Anayasa'nın kararname ile düzenleneceğini belirlediği dört konuda çıkarılacak kararnameler için de geçerli olması doğaldır ${ }^{57}$.

Üçüncü sınırlama "Kanunda açıkça düzenlenen konularda Cumhurbaşkanlığı kararnamesi çıkarılamaz." hükmüdür. Bu hüküm çerçevesinde konusu özel olarak belirlenmiş kararnameler için iki ihtimal söz konusu olabilir. Birinci ihtimal kanunun mahfuz kararname alanında düzenleme yapmış olmasıdır. İkinci ihtimal ise kararnamenin mahfuz alanın dışına çıkarak kanunla düzenlenmiş olan bir konuda düzenleme yapmasıdır. Birinci ihtimalde, mahfuz konularda kanun değil kararname çıkarılacak ise, bu sınırlamasının mahfuz konulu kararnameler açısından işlerliği olmadığı düşünülebilir. Fakat buna rağmen bir kanun çıkarılmışsa, bu kanun iptal edilinceye kadar kanun uygulanacaktır. İkinci ihtimalde, belirlenen mahfuz konunun sınırlarının aşılmasıyla kanunla düzenlenen konularda düzenleme yapılmış olması durumu ortaya çıkar. Mahfuz konunun sınırlarının tespiti güçlüğü, bu durumla karşılaşmayı muhtemel bir hale getirecektir. Bu noktada Anayasa'nın 104/17. maddesinin kanun ve kararname ilişkisi bakımından öngördüğü bir diğer kural devreye girecektir. Buna göre, "Cumhurbaşkanlı̆ğ kararnamesi ile kanunlarda farklı hükümler bulunması halinde, kanun hükümleri uygulanır." Bu hüküm özel konulu kararnamelerin konu sınırını aşarak kanunla düzenlenmiş konulara girmesi halinde kararnamelerin uygulanmasını engeller. Dolayısıyla, Anayasa'nın 104/17. maddesinde yer alan "Kanunda açıkça düzenlenen konularda Cumhurbaşkanlı̆̆ kararnamesi çıkarılamaz." ve "Cumhurbaşkanllğı kararnamesi ile kanunlarda farklı hükümler bulunması halinde, kanun hükümleri uygulanır." düzenlemeleri mahfuz konulu kararnameler için geçerli olacaktır. Mahfuz konulu kararnamenin konu sınırını aşması halinde aşan kısımlarıyla bu niteliğini yitireceği bir gerçek olsa da taşıdığı başlıktan bağımsız ve her durumda 104/17. madde kapsamında yer alması, sorunun çözümünü kolaylaştıracak ve tartışmalı olmaktan kurtaracaktır.

Yukarıda verilen örnekler açısından bakıldığında aynı idari birimi ilgilendiren konuların bir yönüyle kanunla bir yönüyle de kararname ile düzenlenmesinin mevzuat sistematiği açısından fevkalade karmaşık bir norm yapısına yol açacağ öngörülebilir. 
Son olarak, Anayasa'nın 104/17. maddesinin “Türkiye Büyük Millet Meclisinin aynı konuda kanun çıkarması durumunda, Cumhurbaşkanlı̆̆ı kararnamesi hükümsüz hale gelir." hükmü üzerinde durulmalıdır. Kanunun kararnamelere özgülenmiş konularda düzenleme yapmaması beklenir. Bununla birlikte kanunun kararnamelere özgülenmiş konularda düzenleme yapması halinde "Türkiye Büyük Millet Meclisinin aynı konuda kanun çıkarması durumunda, Cumhurbaşkanlığı kararnamesi hükümsüz hale gelir." hükmü yine de uygulanacaktır. Diğer bir deyişle, kanunun kararnamelere özgülenmiş konularda düzenleme yapması Anayasa'ya aykırı olsa da Anayasa'ya aykırı bu kanun kararnamenin yürürlükten kalkmasına sebep olacak ve fakat iptal edilinceye kadar da yürürlükte kalacaktır.

Mahfuz ya da özel konulu kararnamelerin Anayasa'nın 104/17. maddesinden ayrı bir hukuksal rejime tabi olamayacağ 1 görüşünün önem kazandığ 1 alan temel hak ve özgürlüklerin sınırlandırılması rejimiyle ilgilidir. Özellikle bu kararnamelerin kanun gücünde olduğuna yönelik görüşler, Anayasa'nın 13. maddesinin sunduğu "kanun güvencesi"ni etkisizleştirme ihtimalini beraberinde getirmektedir. Bununla birlikte, Anayasa'nın kararnamelerin rejimine ilişkin yarattığ 1 belirsizlikler içinde konularını özel olarak belirlediği kararnamelerin, 104/17. maddesi ile ilişkisini değerlendirerek kesin ve tartışmasız bir sonuca varmak güçtür ${ }^{58}$.

\section{B. Kanun Alanına İlişkin Belirsizlikler}

\section{Münhasır Kanun Alanının Varlığı Sorunu}

Anayasa değişikliğine kadar anayasa hukukumuzda kural olarak münhasır kanun alanının bulunmadığı konusunda hem uygulama hem de öğreti açısından belli bir fikir birliğinin bulunduğu tespit edilebilir ${ }^{59}$. Buna göre, kanunla düzenlenmiş her konuda yürütme organı kanuna dayanmak ve ona aykırı olmamak kaydıyla, kanun açıkça yetki vermese dahi düzenleme yapabilir ${ }^{60}$. Bu açıdan bakıldığında Anayasa değişikliğinin, münhasır kanun alanının var olmadığı durumuna yönelik köklü bir yenilik getirdiği söylenemez. Bununla birlikte Anayasa değişikliğini tasarlayan düşünce yürütme organına asli düzenleme yetkisi tanırken bu yetkinin konu bakımından sınırını "münhasır kanun alanı" kavramını ile belirlemek istemiştir. Her durumda, Anayasa'nın 104/17. maddesindeki “Anayasada münhasıran kanunla düzenlenmesi öngörülen konularda Cumhurbaşkanlığı kararnamesi çıkarılamaz.” düzenlemesini açıklamak gerekecektir. Açıklamayı Anayasa Mahkemesi içtihadı ile ele almak faydalı olabilir.

\footnotetext{
58 Gözler de konuyu farklı ihtimaller çerçevesinde değerlendirip kesin sonuca bağlamamıştır. Gözler (dn 23) 888-889. Ülgen ise özel konulu kararnamelerin 104/17. maddesindeki hükümlerden bağımsız olarak değerlendirilmesi gerektiği sonucuna varmıştır. Ülgen (dn 6) 20-23.

59 Turan Güneş, Türk Pozitif Hukukunda Yürütme Organının Düzenleyici İșlemleri (AÜSBF 1965) 100-115, 132; Erdoğan Teziç, Türkiye'de 1961 Anayasasına Göre Kanun Kavramı (IÜHF 1972) 81; Yıldırım (dn 17) 304; Eren (dn 7) 34-40; Gözler (dn 23) 867; Ülgen (dn 6) 28-29. Bununla birlikte özellikle cezaların belirlenmesinin münhasır kanun alanı olduğu kabul edilir. Gözler (dn 23) 883; Güneș (dn 59) 113.

60 Ülgen, kamu hukukumuzda “...münhasır ifadesi(nin) kanuna mahsus, yürütmeye kapal, yalnızca kanun ile düzenlenebilen alan" olarak anlaşıldığını tespit etmektedir. Ülgen (dn 6) 28.
} 
Anayasa Mahkemesi 2013 yılında konu hakkında verdiği karara kadar ${ }^{61}$, istikrarlı bir içtihat olarak, Kanun Koyucunun yeterli kanun düzenlemesi oluşturmadan konunun detaylarını düzenleyici işlemlere bırakmasını yasama yetkisinin devredilmezliği ilkesi bağlamında Anayasa'ya aykırı buluyordu ${ }^{62}$. Aynı yıl verdiği bir kararla içtihat değişikliğine giden Anayasa Mahkemesi bir ayrıma gitmiş, Anayasa'da kanunla düzenlenmesi emredilen konularda eski içtihadının geçerli olduğuna; ancak bunun dışındaki konularda kanunun sadece belli konularda düzenleme yapması için yürütme organına yetki vermesinin yeterli olacağına hükmetmiştir. Karara göre, "Anayasa temel hak ve özgürlüklerin sınırlandırılması (m.13), vergi ve benzeri mali yükümlülüklerin konması (m.73) ve memurların atanmaları, özlük haklarl v.s. (m.128) gibi bazı konularda düzenlemenin münhasıran kanunla yapılmasını öngörmektedir... Anayasa 'nın açıkça kanunla düzenlenmesini öngörmediği konularda ise kanunun çok genel ifadelerle düzenleme yaparak, ayrıntıy yürütmeye bırakması mümkündür. Anayasa'da münhasıran kanunla düzenleme yapılması öngörülmeyen konularda yürütme organının doğrudan ve ilk elden düzenleyici işlem yapabileceği düşünülebilirse de yasamanın asliliği ve yürütmenin türevselliği gereği idari işlemlerin kanuna dayanması zorunluluğu vardır"63. "Münhasıran kanunla düzenlenmesi gereken konular" ifadesinin Anayasa Mahkemesi tarafindan sadece yasama yetkisinin devredilmezliği ilkesinin yeniden yorumlanması bağlamında kullanıldığı; yoksa bu konuların yeterli kanun düzenlemesi bulunduğu sürece, yürütmenin düzenlemesine tamamen kapatılmış konular olarak görülmediği açıktır. Bununla birlikte, Anayasa'nın 104/17. maddesindeki hükmün bu içtihat değişikliğinin kullandığı kavramdan etkilenilerek tasarlandığı ileri sürülebilir ${ }^{64}$. Diğer bir deyişle, Anayasa'nın söz konusu hükmünü Anayasa Mahkemesinin kararlarında dile getirdiği şekilde yorumlayabiliriz.

Anayasa'nın 104/17. maddesinde yer alan "münhasıran kanunla düzenlenmesi öngörülen konular” ifadesinin, "Anayasa' da 'ancak kanunla' düzenlenir veya sınırlanır şeklinde ifade edilen durumlara mı işaret ettiğì"ne dair bir soru kaçınılmazdır. "Ancak kanunla" ifadesinin geçtiği 13/1. ${ }^{65}, 20 / 3 .{ }^{66}, 38 / 3 .{ }^{67}, 66 / 3 .{ }^{68}$ maddeler zaten Anayasa'nın ikinci kısmının birinci ve ikinci bölümlerinde bulunan temel haklar, kişi hakları ve ödevleri ile dördüncü bölümde bulunan siyasi haklar ve ödevler düzenlemeleri içinde yer alır ve bunlar kararnameler için zaten mutlak yasak alanlardır. Geriye bir tek Anayasa'nın 66/8. maddesindeki "Yüksek öğretim elemanlarının siyasi partilere üye olmaları ancak kanunla

\footnotetext{
Anayasa Mahkemesi, 76/44, 20.03.2013

Anayasa Mahkemesinin bu konudaki oldukça sorunlu içtihat birikimi ve bunun eleştirisi için bkz. Öztürk (dn 3) 144-150.

63 Anayasa Mahkemesi, 72/126, 24.02.2013.

64 Yildırım (dn 5) 25.

${ }^{65}$ "Temel hak ve hürriyetler, özlerine dokunulmaksızın yalnızca Anayasanın ilgili maddelerinde belirtilen sebeplere bağll olarak ve ancak kanunla sinırlanabilir."

66 "Kişisel veriler, ancak kanunda öngörülen hallerde veya kişinin açık rızasıyla işlenebilir."

67 "Ceza ve ceza yerine geçen güvenlik tedbirleri ancak kanunla konulur."

68 "Vatandaşlık, kanunun gösterdiği şartlarla kazanılır ve ancak kanunda belirtilen hallerde kaybedilir."
} 
düzenlenebilir." hükmü kalmaktadır ${ }^{69}$. Her halde "münhasıran kanunla düzenlenmesi öngörülen konular" ölçütü sadece 66/8. madde kast edilerek getirilmemiştir. Dolayısıyla "münhasıran kanunla düzenlenmesi öngörülen konular" ifadesi ile "ancak kanunla düzenlenir" ifadesinin kast edilmiş olması mümkün görünmemektedir ${ }^{70}$.

Neresinden bakarsak bakalım düzenlemede geçen "münhasır" sözcüğünün kullanılması uygun olmamıştır. Gereksiz yere kullanılan "münhasır" sözcüğünün bulunması ya da bulunmamasının düzenlemeyle güdülen amaç bakımından büyük bir anlam farkı doğurmayacağı düşünülebilir. Düzenlemenin tek anlamı çok basit düzeyde, "Anayasa'da kanunla düzenlenmesi öngörülen konularda" kararname çıkarılamayacağıdır ${ }^{71}$. Diğer taraftan "münhasır" sözcüğüne mutlaka bir anlam yüklenecekse bunun kanuna dayanan düzenleyici işlemler bakımından bir anlamı olmadığı bellidir. Bu açıdan, münhasır alanının varlığının sadece asli düzenleme yetkisini ifade eden kararnameler bakımından söz konusu olduğu ileri sürülebilir. Diğer bir deyişle, yürütme organının düzenleme yetkisi kanuna dayanmak zorunda olmayan kararnameler ve kanuna dayanmak zorunda olan diğer düzenleyici işlemler çıkarmak şeklinde iki kategori olarak ele alınacaksa, burada söz konusu olan münhasır kanun alanı sadece kararnamelere kapatılmış konuları ifade eder. Eğer böyle ise, münhasır kanun konularının bir listesinin yapılmamış olması bir eksiklik değildir. Anayasa'da hangi konuların kanunla düzenleneceği bellidir.

Konunun sosyal ve ekonomik haklar bakımından ele alınması gerekecektir. Gözler'in "düzenleme" ve "sınırlama" kavramları arasında fark bulunduğuna ilişkin kabulü ile ileri sürdügü görüşe göre, Anayasa'nın 13. maddesi, hangi bölümde yer alırsa alsın, temel hak ve özgürlüklerin "sınırlanması"nın "kanun" ile olacağını emretmektedir ve bu kapsamda kararnameler sosyal ve ekonomik hakları sadece düzenleyebilir, sınırlayamaz ${ }^{72}$. Bu açıklamanın "sınırlama" ve "düzenleme" kavramsal farklılığına yönelik kısmının doğru olduğu kabul edilecek olsa bile, Anayasa'nın 104/17. maddesinde yer alan "münhasiran kanunla düzenlenmesi öngörülen konular" ifadesi karşında sosyal ve ekonomik haklar alanında da kanunla düzenleneceği belirlenmiş konularda "düzenleme amacı" ile dahi kararname çıkarılmasının mümkün olmadığını kabul etmek durumundayız. Örneğin Anayasa'nın 42. maddesinde göre, "Öğrenim hakkının kapsamı kanunla tespit edilir ve düzenlenir"; "Özel ilk ve orta dereceli okulların bağgl olduğu esaslar, Devlet okullart ile erişilmek istenen seviyeye uygun olarak, kanunla düzenlenir"; "Eğitim ve öğretim kurumlarında okutulacak yabancı diller ile yabancı dille eğitim ve ögretim yapan okulların tabi olacağı esaslar kanunla düzenlenir." O halde, sosyal ve ekonomik haklar kısmında düzenlenen eğitim öğretimle ilgili kanunla düzenleneceği belirlenmiş bu konularda sınırlama içermese dahi

\footnotetext{
69 Bu düzenlemenin de siyasi haklar ve ödevlerden bağımsız bir içeriğe sahip olduğu düşünülemez.

70 Farklı gerekçelerle aynı sonuç için bkz. Gözler (dn 23) 884.

71 Aynı yönde bkz. Sancaktar (dn 13) 82; Ülgen (dn 6) 29-33; Yıldırım (dn 5) 26.

72 Gözler (dn 23) 882.
} 
kararname çıkarmak mümkün değildir ${ }^{73}$. Yine Anayasa'nın 51/3. maddesine göre, "Sendika kurma hakkının kullanılmasında uygulanacak şekil, şart ve usuller kanunda gösterilir."; 54/1. maddesine göre, "Toplu iş sözleşmesinin yapılması sırasında, uyuşmazlı çıkması halinde işçiler grev hakkına sahiptirler. Bu hakkın kullanılmasının ve işverenin lokavta başvurmasının usul ve şartları ile kapsam ve istisnaları kanunla düzenlenir." Anayasa'nın üçüncü bölümünde kanunla düzenleme şartı getirilen (md. 42/9, 43/3, 44, 46, 47, 50/4, 51/4, 53/(2)(5), vs.) birçok hüküm daha mevcuttur. Şüphesiz Anayasa'nın öngördügü yasak kapsamında bu konularda kararname çıkarılması mümkün görünmemektedir.

Bütün bu açılardan bakıldığında sosyal ve ekonomik haklar bakımından kararnamelerin düzenleme olanağı geçmişteki kanun hükmünde kararnamelere göre çok daha sınırlıdır ${ }^{74}$.

\section{Kanunda Açıça Düzenlenen Konular Sorunu}

Anayasa'nın 104/17. maddesinin kararnameler için getirdiği konu sınırlamalarını yukarıdaki başlıklar altında büyük ölçüde incelemiş olduk. Aynı maddede geçen "Kanunda açıkça düzenlenen konularda Cumhurbaşkanlı̆̆ı kararnamesi çıkarllamaz." sınırlaması, yukarıda açıklamaya çalıştı̆̆ımız birçok soruna ek bazı sorunları beraberinde getirecekmiş gibi görünmektedir. Hatta kararname ve kanun ilişkisi bakımından en çok tartışılacak konulardan birisinin de bu olacağı tahmin edilebilir.

Kanunların ele aldıkları konuyu "örtülü" olarak düzenlenmesi değil, "açıkça" düzenlemeleri beklenir. Bir konu kanunla düzenlenmiş ise açıkça düzenlenmiştir ${ }^{75}$. Bu bakımdan "kanunda düzenlenen konular" ifadesi ile "kanunda açıkça düzenlenen konular" arasında nasıl bir anlam farkı bulunduğunu açıklamaya çalışmak sonuçsuz bir çaba olacaktır ${ }^{76}$. Bununla birlikte Şirin bu konuda oldukça işlevsel görünen bir ölçüt önermektedir. Buna göre, “...herhangi bir kuralın uygulamasını değiştiren veya yorumuna etki eden düzenlemeleri 'aynı konuda' saymak gerekir."’’7 Bu ölçüt karşılaşılması muhtemel sorunların üstesinden büyük ölçüde gelecek olsa da norm dünyasının karmaşık yapısı içinde bazı sorunları çözmek için yeteri olmayabilir.

\footnotetext{
Eren'e göre, "Sosyal ve ekonomik haklar alanında kanunla düzenleme öngören hükümler içinde ikincil nitelikteki düzenlemeler yapılabilir. Nitekim Anayasa Mahkemesi'ne göre, 'Anayasa'nın 42. maddesinde yer alan, 'Öğrenim hakkının kapsamı kanunla tespit edilir ve düzenlenir. 'hükmü de, öğrenim hakkına ilişkin her konunun mutlaka kanunla düzenlenmesi zorunluluğunu içermemekte, kanunla ögrenim hakkına ilişkin bir düzenleme yapılmaksızın söz konusu düzenleme yetkisinin tamamen yürütme organına birakılamayacă̆ını ifade etmektedir' (AYM, E. 2014/88, K.2015/68, 13/7/2015. \$. 65). Dolayısıyla konu kanunla ilk elden düzenlendikten sonra, konunun kanun dışında kalan alanlarına ilişki CBK ile düzenleme yapilabilir." Eren (dn 7) 39.

74 Eren (dn 7) 66. "Münhasıran kanunla düzenlenmesi öngörülen konular” sorununun bazı yönlerini, “yürütme yetkisine ilişkin konular" sorunu bağlamında aşağıda tekrar ele alacağız.

75 Elbette hukuk dilinde, belli bir düzenleme yorumlanırken "açık düzenlenme" bulunmadığı ya da konunun "açıkça düzenlendiği" gibi nitelendirmeleri sıklıkla kullanırız. Ancak yukarıda üzerinde durduğumuz "kanunda açıkça düzenlenen konular" ifadesinin, yorum çabası sırasında sarf ettiğimiz "açıkça düzenleme"ye dair nitelendirmelerden farklı olduğu bellidir.

76 Gözler (dn 23) 885-886.

$77 \quad$ Şirin (dn 9) 332.
} 
"Açıkça" sözcüğü ile Cumhurbaşkanının belli bir konuda düzenleme yapmış olan kanunda bazı eksiklikler olduğunu düşünmesi halinde kararname çıkarması olanağı yaratılmak istenmiş olabilir. Bazı konular kanunda düzenlenmiş, ancak o konuda kanunda bulunmayan bir kısım ek düzenlemelere ihtiyaç duyulduysa, bu ek düzenlemeler kararname ile yapılabilir mi? Bu soruya olumlu yanit verilse bile Kanun Koyucunun belli bir konunun bilinçli olarak düzenlemediği bir unsurunu Kanun Koyucudan farklı olarak eksiklik ya da ihtiyaç olarak gören bir Cumhurbaşkanının kendince düşündüğü bu eksikliği gidermesi kendisini Kanun Koyucunun yerine koyduğu anlamına gelmez mi? Kanunun artık toplumsal ihtiyaçları karşılama özelliğini yitirmiş olması ile Kanun Koyucunun belli bir konu unsurunu bilinçli olarak düzenlememiş olması arasındaki farkın tespit edilmesi mümkün müdür? Bu sorulara tatmin edici açıklıkta cevaplar vermek mümkün değildir. Ancak şurası bir gerçek ki Cumhurbaşkanının, kanunun son derece genel bir şekilde düzenlediği ve ayrıntılarının da örneğin yönetmelik gibi bir düzenleyici işlemle düzenleneceğini de zikretmediği bir konuda kararname ile kanunu dayanak göstermeden ayrıntılı düzenlemeler getirmesi mümkün değildir. Cumhurbaşkanı ayrıntılara dair düzenleme yapmak ihtiyacı duyduğunda bunu ancak yönetmelikle yapabilecektir.

Cumhurbaşkanın kanunda eksik olarak düşündüğü bir unsuru kararname ile düzenlemesi konusunda yetkisinin bulunduğunu düşünsek bile mevzuat sistematiği açısından oldukça karmaşık bir norm yapısı oluşacağı kesindir. Aynı konunun belli yönleri kanunla belli yönleri ise kararname ile düzenlenmiş olabilecektir.

Yine herhalde belirtmeye gerek yoktur ki kararname ile kanun metnine ek yapılmasının mümkün olmaması gerekir. Aksi halde normlar hiyerarşisinde aynı seviyede olmayan, bir kısmı kanun bir kısmı kararname olan melez metinler ortaya çıkacaktır ${ }^{78}$. Uygulamada kararname ile kanuna ek yapılmasına yetki verildiği ve bu yetkinin de kullanıldığını görmekteyiz ${ }^{79} .5018$ sayılı Kamu Mali Yönetimi ve Denetimi Hakkında Kanun'un Ek Madde 5'e göre, “Cumhurbaşkanlı̆̆ kararnameleriyle kurulan idarelerin bu Kanuna ekli cetvellerden hangisinde yer alacă̆ ilgili Cumhurbaşkanlı̆̆ kararnamesinde belirtilir." Bugüne kadar sekiz kuruluş kararnameler ile Kanun’un ekli cetveline eklenmiştir. Ek Madde 5'ten Kanun'a ek yapılması anlamı çıkıp çıkmayacağı bir tarafa, kararnameler açıkça Kanun'a ek yapılmasını düzenlemiştir. Örneğin, 23 sayılı Kararname'nin ${ }^{80}$ 11/4. maddesine göre, “10/12/2003 tarihli ve 5018 sayılı Kamu Mali Yönetimi ve Kontrol Kanununa ekli (II) Sayılı Cetvelin 'B) ÖZEL

\footnotetext{
78 Geçmişte kanun hükmünde kararnameler rejimi kapsamında benzer bir sorunun tartışıldığı ilginç bir makale için bkz. Cem Eroğul, “TBMM YGK'lerde Değişiklik Yapabilir mi?” (2005) 60(3) Ankara Üniversitesi Siyasal Bilgiler Fakültesi Dergisi 109-121.

79 Ülgen, örnekleriyle birlikte aynı sorunu ele alırken kanunun, kararname ile kanunda değișiklik yapılabilmesine yetki vermesinin; türev nitelikte bir düzenleme yetkisine işaret ettiğini bunun ise kararnamelere ilişkin hukuksal rejimle bağdaşmayacağını ifade etmektedir. Ülgen (dn 84) 268. Ancak unutmamak gerekir ki kararname adı altında olmasa da mevcut Anayasa düzenlemeleri çerçevesinde türev nitelikte bir düzenleme yetkisi ile kanuna ek yapmak da mümkün değildir.

80 RG 13.12.2018/30624.
} 
BÜTÇELİ DİĞER IDARELER' bölümüne '50) Türkiye Uzay Ajansı' satırl ilave edilmiştir." Böylece ortaya bir kısmı kanun bir kısmı kararname olan bir düzenleme metni ortaya çıkmıştır. Böyle bir durumu Anayasa hükümleri çerçevesinde belli bir anlama kavuşturmak mümkün değildir. Elbette Cumhurbaşkanı tarafindan kurulan kamu tüzel kişilerinin bütçe rejiminin belirlenmesi gerekir. Ancak bunun için 5018 sayılı Kanun'a kararname ile ek yapılması zorunlu değildir ${ }^{81}$. 5018 sayılı Kanun'a kararname ile yapılan eklerin kişilerin hakları ve yükümlülüklerini ilgilendiren bir yönü bulunmadığı; dolayısıyla önemli bir sorun olarak düşünülmemesi gerektiği ifade edilebilir. Ancak, bu durum sorunların hangi boyutlara sahip olduğuna veya olabileceğine dair ilginç bir örnektir.

Kanunun düzenleme konusunu "amaç" ve "kapsam" maddeleriyle belirlemenin en doğru yol olduğu düşünülebilir. Bu maddelerin kanunun konusunu ve amacını son derece genel ifadelerle belirlediği bir gerçektir. Bu ifadeler ne kadar genel olursa olsun belli bir alanın kanunla düzenlendiğine işaret eder. Örneğin 18/04/2006 tarih ve 5488 sayılı Tarım Kanunu'nun 1. ve 2. maddesi amaç ve kapsamını ortaya koymuştur. Kanun'un 2. maddesine göre, “Bu Kanun, tarım politikalarının amaç, kapsam ve konularının belirlenmesi; tarımsal destekleme politikalarının amaç ve ilkeleriyle temel destekleme programlarının tanımlanması; bu programların yürütülmesine iliş̧kin piyasa düzenlemeleri, finansman ve idarî yapılanmanın tespit edilmesi; tarım sektöründe uygulanacak öncelikli araştırma ve gelişstirme programlarlyla ilgili kanun $\hat{\imath}$ ve idarî düzenlemelerin yapılması ve tüm bunlarla ilgili uygulama usûl ve esaslarını kapsar." Burada belirlenen konulara temas eden hiçbir konu artık kararname ile düzenlenmemelidir. Daha eski tarihli kanunlarımızda amaç ve kapsam belirleme maddeleri bulunmamaktadır. Bununla birlikte uygulayıcının amaç ve kapsam maddeleri bulunmayan bir kanunu bütünüyle inceleyip amaç ve kapsamını belirlemesi güçlük arz etmese gerekir.

\section{Düzenleme Yetkisinde Yasama ve Yürütme Ortak Alanı}

Anayasa'nın 104/17. maddesi kararnamelerin konusunu belirlerken "yürütme yetkisine ilişkin konular" ifadesini kullanmaktadır. Yürütme yetkisine ilişkin konularda yasama yetkisinin genelliğine ilişkin bir tartışma bulunmamaktadır. Zira yürütme yetkisine ilişkin konularda kanun çıkarılabilecektir. O halde yürütme yetkisine ilişkin konular yasama ve yürütmenin ortak düzenleme alanı olarak belirlenmiştir. Bu konuda sorun yürütme yetkisine ilişkin konuları tanımlamaktır (A).

Yasama ve yürütmenin ortak düzenleme alanı olarak en az tartı̧̧malı konu kamu tüzel kişiliğinin kurulması olmalıdır. Çünkü Anayasa’nın 123/3. maddesi kamu tüzel

1 Yukarıda verdiğimiz örnekte "Türkiye uzay Ajansı 5018 sayll Kamu Malî Yönetimi ve Kontrol Kanununa ekli (II) Sayll Cetvelin 'B) ÖZEL BÜTÇELİ DIGGER IDARELER' bölümündeki idareler statüsünde kabul edilir." şeklinde bir düzenleme yapılması sanırız sorunu çözmek için yeterli olurdu. Nitekim 5018 sayılı Kanun'un Ek Madde 5'inde yer alan düzenleme de bu türden bir çözümü destekler niteliktedir. 
kişiliğinin kanunla veya kararname ile kurulabileceğini belirlemekle kararnamelere ilişkin diğer düzenlemelere oranla daha belirgin bir düzenleme getirmiştir (B).

\section{A. Yürütme Yetkisine İlişkin Konular Sorunu}

Anayasa'nın 104/17. maddesi Cumhurbaşkanının yürütme yetkisine ilişkin konularda kararname çıkarabileceğini, bu konularda kanun çıktığında ise kararnamenin hükümsüz hale geleceğini düzenlediğine göre, "yürütme yetkisine ilişkin konular” kararname ve kanunların ortak düzenleme alanıdır. Elbette "yürütme yetkisine ilişkin konular" ifadesi kanun ve kararnamenin ortak alanını ifade etmenin yanında, kararnamelere ilişkin konu sınırını da belirlemiş olmaktadır. Diğer bir deyişıle yürütme yetkisine ilişkin konular dışında kararname çıkarılması mümkün değildir.

Anayasa'nın özel olarak belirlediği dört konuda ve kamu tüzel kişiliğinin kuruluşu konusunda kararname çıkarma yetkisinin konu bakımından sınırları göreli olarak bellidir. Ancak özel olarak belirlenen konuların dışında, kararnameler için getirilen genel konu belirlemesi ya da sınırlaması "yürütme yetkisine ilişkin konular" olarak ifade edildiğinde bunu tanımlama gereği doğar ve bunu yapmak hiç de kolay değildir ${ }^{82}$. Daha önce de belirtildiği gibi Anayasa'da kararnameler için belirlenen özel konuların bizzat Kanun Koyucu tarafından yürütme yetkisine ilişkin konular kapsamında görüldüğü düşünülebilir. Ancak bunun dişında yürütme yetkisine ilişkin konuların neler olduğu bugüne kadar ne öğretide ne de yargı kararlarında tanımlanmış değildir.

Anayasa'nın "yürütme yetkisi" olarak ifade ettiğinin "yürütme fonksiyonu" olduğunu düşünebilir miyiz? Maddi anlamda yürütme fonksiyonu, anayasa değişikliğine kadar, hükümet fonksiyonu adını verdiğimiz siyasi işleri ve "kanunların uygulanması" çerçevesindeki işleri (idari işlevi) ifade eden belli bir anlama sahipti. Özellikle kanunların uygulanması etkinliği bakımından "yürütme görevi”nden söz ediyorduk. Yürütmenin bir kanuna dayanarak gerçekleştirdiği düzenleyici işlemlerin de "kanunun uygulanması" kapsamında görülmesi olağand1. Bugün de yürütme fonksiyonunun kanunları uygulama yönü asli bir özelliktir. Ancak, kanunla düzenlenmemiş konularda ve asli düzenleme yetkisi bakımından yürütme fonksiyonunun (ya da görev ve yetkisinin) ne anlama geldiğini açıklayacak belirgin bir ölçüt bulunmamaktadır. Kararnameler bir kanuna dayanmak zorunda değilse, yürütme fonksiyonunu "kanunları uygulama fonksiyonu" şeklinde tanımlamak sorunu çözmez. Yine de soruna bu açıdan bakalım ve yürütme fonksiyonunu bu sefer kanun ve kararnamenin yürütmeye verdiği görev ve yetkiler olarak tanımlayalım. Bu açıdan bakıldığında yürütme fonksiyonunun kendi halinde bir anlama sahip olmadığı, kanun ve kararnamenin yürütmeye verdiği görev ve yetkiler bulunmadığg sürece yürütme fonksiyonundan söz edilemeyeceği açıktır. Yürütme fonksiyonu kanun ve kararnamenin

82 Atar (dn 16) 247. Söz konusu güçlüğün yürütme fonksiyonu açısından örneklerle açıklaması için bkz. Ulusoy (dn 13) 38-55. 
belirlediği bir şey ise bunun aynı zamanda kanun ve kararnamenin önceden belirlenen konusu olması mümkün değildir. Diğer bir deyişle bir fonksiyon tamamen açılanan iradenin tercihine göre ve onun sonucu olarak var olabiliyorsa o fonksiyonun konusunu önceden genel bir ifade ile belirlemek mümkün değildir. Elbette "yürütme yetkisine ilişkin konular" gibi genel bir ifade yerine somut olarak belirlenmiş olan belli konuların bir listesinin yapılması mümkündür. Anayasa'da yapılması gereken değişikliklerden birisi belki de buydu. Nitekim yukarıda da bazı belirttiğimiz üzere Anayasa'nın 104/9, 106/11, 108/4, 118/6 maddeleri kararnamelere ilişkin bazı somut konuları belirlemiş bulunmaktadır. Yine Anayasa'nın 123/3. maddesi kamu tüzel kişiliğinin kanunla veya kararname ile kurulabileceğini öngörmektedir. $\mathrm{Bu}$ türden somut belirlemeler yapılmadığı sürece "yürütme yetkisine ilişkin konularda" kararname çıkarılabileceğini düzenlemenin, kararnamelere ilişkin bir konu sınırlaması getirmek bakımından hiçbir işlevselliği ve anlamı yoktur. Benzer sebeplerle kararnamelerin konusunu belirlemek bakımından "Yasama ve yargı fonksiyonu dışında kalan her konu yürütme fonksiyonuna dahildir" şeklinde düşünmenin, belirsizliği giderme çabasına bir katkı sunmayacağını ifade edebiliriz ${ }^{83}$.

Yürütme yetkisi idari teşkilat, görev ve yetkilere ilişkin ve kararname ile bunların düzenleneceği kast edilmiş ise, Anayasa' da özel olarak belirlenen dört konu ve kamu tüzel kişiliğinin kuruluşu dışında bunun da mümkün olmadığı ileri sürülebilir. Zira Anayasa'nın 123/1. maddesine göre, "İdare, kuruluş ve görevleriyle bir bütündür ve kanunla düzenlenir." Gerçekten idare kuruluş ve görevleri ile "kanun" ile düzenlenecekse; Anayasa' da (münhasiran) kanunla düzenlenmesi emredilen konularda da kararname çıkarılamayacaksa, Cumhurbaşkanı yürütme yetkisine ilişkin hangi konuda kararname çıkarabilecektir? "Yürütme yetkisine ilişkin konular" ifadesi ile "idarenin kuruluş ve görevleri" ifadesi arasındaki ilişki nedir? Acaba "Yürütme yetkisine ilişkin konular", "idarenin kuruluş ve görevleri”"ne ilişkin konulardan daha fazlasını mı içermektedir? Eğer öyle ise, hükümet işlevi (siyasi işlev) dışında, "daha fazlası" konuları bakımından belirlenebilir mi?

$\mathrm{Bu}$ sorulara ikna edici cevaplar vermek güçtür. Öncelikle belirtmek gerekir ki Anayasa'nın 104/17. maddesi "Cumhurbaşkanının yürütme yetkisine ilişkin konularda kararname çıkarabileceği" ile 123/1. maddesinde yer alan "idare kuruluş ve görevleri ile kanunla düzenlenir” hükümleri arasında genel hüküm, özel hüküm ya da kural, istisna ilişkisi kurmak mümkün değildir. Çünkü bu ilişkiyi ortaya koyabilmek için "yürütme yetkisine ilişkin konular" ifadesini netleştirmek gerekir. Yukarıda da belirtildiği gibi bu ifadeyi anlaşlır, nesnel ve öngörülebilir bir anlama kavuşturmak ise pek mümkün görünmüyor. Gerçekten "Anayasa'da münhasıran kanunla düzenlenmesi öngörülen konular" ifadesinden "Anayasa'da kanunla düzenlenmesi öngörülen konular” anlaşılacaksa, Anayasa'da konusu açıkça belirlenmiş kararnameler

Öztürk (dn 3) 91-93. 
dışındaki kararnamelerle (yeni bir kamu tüzel kişiliğinin kurulması dışında) idari teşkilat, görev ve yetkilerin kararname ile düzenlenememesi gerekir. Bu bakımdan örneğin Cumhurbaşkanlığ idari teşkilatı ve bu teşkilatın görev ve yetkilerinin mutlaka kanunla düzenlenmesi gerekirdi. Diğer taraftan Cumhurbaşkanının Anayasa'da belirlenenler dışında sahip olacağı bütün yetkilerin kanundan kaynaklanması gerekir. Zira Anayasa'da başkent teşkilatında bakanlık teşkilat, görev ve yetkilerinin kararname ile düzenleneceği düzenlenmiş olmakla birlikte, Cumhurbaşkanlığı teşkilatı ve bu teşkilatın görev ve yetkilerinin kararname ile düzenleneceğine ilişkin açı bir hüküm bulunmamaktadır ${ }^{84}$. Oysa 1 sayılı Cumhurbaşkanlığı Kararnamesi'nin 1. maddesinden 37. maddesine kadar Cumhurbaşkanlığının idari teşkilatı düzenlenmiştir.

Geldiğimiz noktada Cumhurbaşkanlığı idari teşkilatının kararname ile düzenlenemeyeceği; 1 sayılı Cumhurbaşkanlığı Kararnamesi’nin Cumhurbaşkanlığı teşkilatını düzenleyen maddelerinin ise Anayasa'ya aykırı olduğunu güçlü gerekçelerle ileri sürmek mümkündür ${ }^{85}$.

Yukarıdaki tartışmamız “yürütme yetkisi”nin hangi konuları içerdiğine dair soyut bir belirleme yapma zorluğunun ötesinde; meseleye diğer Anayasa hükümleri çerçevesinde baktı̆̆ımızda da belirsizliklerin ciddi boyutta olduğunu göstermek içindi. Söz konusu belirsizliği göstermek adına birçok örnek üzerinde durulabilir ${ }^{86}$.

$\mathrm{Bu}$ başlık altında tartışılan sorunun kararnamelerin bir kanuna dayanmak zorunda olmaması ve kanun gücünde olmamasından kaynaklandığı açıktır. Yukarıda Yıldırım'ın kararnamelerin bir yetki kanuna dayanması gerektiğine dair görüşlerine yer vermiştik. $\mathrm{Bu}$ görüş açısından kanunla yetki verilen konunun yürütme yetkisine ilişkin konu olduğu düşünülebilir. Ancak bu durumda da yetki kanununun Anayasa’ya uygunluğu açısından yürütme yetkisine ilişkin konular dışına çıkıp çıkmadığı tartışılacaktır. Belki bu konuda kanun koyucunun takdir yetkisinin bulunduğu kabul edilerek tartışmanın bir çözüme kavuşması sağlanabilir. Bu çözüm kararnamelerin kanuna dayanması gerektiğini kabul ettiğgimizde mümkündür ve son derece işlevseldir ${ }^{87}$. Peki kararnamelerin

${ }^{84}$ Bakanlıkların kararname ile düzenlenmesini öngören Anayasa değişikliğinin Cumhurbaşkanlığı teşkilatı hakkında buna benzer bir hüküm getirmemiş olması ilginç bir durumdur. Zira Cumhurbaşkanlığı bakanlıklardan ibaret değildir. Bu durum, Anayasa değişikliği metninin hazırlanması aşamasında Cumhurbaşkanlığı teşkilatının kararname konusu yapılmasının unutulmuş olması ihtimalini akıllara getirmektedir. Özen Ülgen, 'Cumhurbaşkanlığı Kararnameleri: İlk Gözlemler' (2018) 2 Galatasaray Üniversitesi Hukuk Fakültesi Dergisi 619, 630; Ulusoy (dn 13) 118, 293.

85 Yıldırım'a göre başkanlık sistemi mantığı içinde sadece "Cumhurbaşkanlığı teşkilatı Cumhurbaşkanlığı Kararnamesiyle düzenlenir" ş̧eklinde bir hüküm getirilmiş olması, bakanlıkların kurulması ve kaldırılması yetkisini de içerecek yeterli düzenleme olurdu. Yıldırım (dn 17) 312. Ulusoy'a göre, mevcut sistem içinde bakanlıklarla Cumhurbaşkanlığı teşkilatını ayrı düşünmek mümkün olmadığına göre bakanlıkları kararname ile düzenleme yetkisine sahip olan Cumhurbaşkanının Cumhurbaşkanlığı teşkilatını düzenleme yetkisine evleviyetle sahip olduğunu kabul etmek gerekir. Ulusoy (dn 13) 119.

86 Örneğin, Gözler yargı örgütünün, yüksek mahkeme teşkilatının yargı fonksiyonunu ilgilendiren bir konu olmadığını; bu konuların yürütme yetkisine ilişkin konular olarak kabul görmesi halinde yargı örgütünün bir kararname ile düzenlenebileceğine dikkat çekmektedir. Gözler (dn 23) 879. Neyse ki Anayasa'nın (münhasıran) kanunla düzenleneceğini emrettiği konularda kararname çıkarılamayacağı hükmü, bu tür sorunların üstesinden gelmemize yardımcı olabilir. Zira Anayasa yargı teşkilatı ve personeline ilişkin hemen her konuyu 138. ve devamı maddelerinde kanunla düzenleme şartına bağlamıştır.

87 Aynı yönde bkz. Şirin (dn 9) 309. 
kanuna dayanmak zorunda olmadığı görüşü bakımından benzer bir çözüm üretmek mümkün müdür? Şirin, haklı olarak kararnamelerin ihdas usulüne dair bir kanun çıkarılmasının önünde anayasal bir engel bulunmadığına dikkat çekmektedir ${ }^{88}$. Bu açıdan bakıldığında, "ihdas usulü”nün de ötesinde Kanun Koyucunun sahip olduğu takdir yetkisine bağl1 olarak kararnamelerden daha güçlü olan kanunla "yürütme yetkisine ilişkin konular" $n$ bir listesini yapması ve kararname çıarma yetkisini konu bakımından belirgin bir sınıra kavuşturması ihtimali tartışılmalıdır. Bu tür bir yöntemde Anayasa'nın 104/17. maddesindeki sınırlamalar varlığını sürdürecektir. Kararnameler kanun gücünde olmadığına göre ve Kanun Koyucu yürütme yetkisine ilişkin konularda kanun çıkardığında kararname yürürlükten kalkacağına göre ve yasama yetkisinin genelliği ilkesi gereği Kanun Koyucunun yürütme yetkisine ilişkin konuları belirleme ve kararnamelerin de belirlenen konular dışına çıkamayacağını emretme yetkisine sahip olduğu ileri sürülebilir ${ }^{89}$. Önerilen bu çözüm sorunsuz değildir. Öneriye göre kanunla belirlenen konuların kararname ile aşılması halinde kararnamenin karşılaşacağ müeyyidenin ne olacağı sorusunun cevabı belirsizdir. Böyle bir durumda kararnamenin kanuna aykırı olduğu düşünülebilir. Ancak yargısal denetimi Anayasa’ya uygunlukla sınırlı olan kararnamelerin kanuna aykırı olduğunu ileri sürmek mümkün görünmemektedir. Bununla birlikte kanunun belirlediği konu sınırlamasının aşılması halinde sorunun Anayasa'nın 7. ve 8. maddesi çerçevesinde değerlendirilmesi mümkündür. Anayasa'nın 7. maddesi yasama yetkisinin üstünlüğünü devredilemeyecek bir yetki vurgusuyla belirlemektedir. Anayasa'nın 8. maddesi ise yürütmenin görev niteliğini sürdürmektedir. Kanun koyucunun yürütme yetkisine ilişkin konuları kanunla somutlaştırması halinde yürütmenin görev niteliği öne çıkacaktır. Dolayısı ile kanunun belirlediği sınırların aşılması Anayasa'nın 7. ve 8. maddesine aykırılıkla nitelendirilebilir. Elbette kararnamenin Anayasa'ya uygunluğunu bir kanuna uygunluğu açısından değerlendirmek denetim tekniği açısından sorunludur. Fakat en azından kanun hükmünde kararnamelerin yetki kanununa uygunluğunun değerlendirilmesine dair tartışmalı geçmiş deneyimlerimiz mevcuttur.

Bütün bu tartışmadan ortaya çıkan sonuç açıktır. Yukarıda da belirtildiği gibi, yürütme organının düzenleme aracı olarak kararnameler üzerinde ısrar edilecek ise, yürütme yetkisine ilişkin konuların bu ifadeye yer verilmeden bir liste halinde Anayasa'da belirlenmesi gerekir. Daha yerinde bir tercih yürütme yetkisine ilişkin kararnameler kategorisinin tamamen yürürlükten kaldırılması ve sadece belirlenen özel konularda kararname çıkarma yetkisinin tanınmasıdır. Her durumda bu konuda bir Anayasa değişikliğine ihtiyaç olacaktır.

Neticede, mevcut düzenlemeler çerçevesinde, ortak alan olarak nitelendirdiğimiz yürütme yetkisine ilişkin konularda çıkarılan kararnamelerin konu sınırlarını aşıp

89 Aksi yönde bkz. Volkan Aslan, 'Cumhurbaşkanlığı Kararnamelerinin Kanunlara Uygunluğunun Denetimi ve Çeşitli Hususların Kararname ile Düzenleneceğinin Kanunlarda Belirtilmesi Üzerine’ (2019) 36(1) Anayasa Yargısı 139, 154-158. 
aşmadığ1 sorununun doğru bir hukuksal temellendirme ile makul çözümlere kavuşturulması pek mümkün görünmüyor.

\section{B. Kamu Tüzel Kișiliğinin Kurulması}

Yukarıda konusu özel olarak belirlenmiş kararnamelerin Anayasa’nın 104/17. maddesi kapsamının dışında düşünülmesinin mümkün olmadığını açıklamaya çalışmıştık. Anayasa'nın 123/3. maddesi kamu tüzel kişiliğinin kanunla veya kararname ile kurulabileceğini öngörmektedir. Bu kapsamda kamu tüzel kişiliğinin kuruluşuna ilişkin kararnamelerin de Anayasa'nın 104/17. maddesi kapsamında yer aldığı açıktır. Anayasa'nın genel hüküm niteliğindeki 104/17. maddesi ve 123/3. maddesi kanun ve kararname için ortak düzenleme konularını içerdiğine göre bu sonuç olağandır.

Yukarıda Anayasa'da (münhasıran) kanunla düzenlenecek olan konularda kararname çıkarılamayacağına ilişkin kural ele alınmıştı. Bu çerçevede kararname ile kamu tüzel kişiliği kurulabileceğine ilişkin Anayasa'nın 123/3. maddesi, idarenin kanunla düzenlenmesi kuralını ifade eden 123/1. maddesine istisna oluşturur ${ }^{90}$.

Kamu tüzel kişiliğinin kuruluşuna ilişkin kararnameler söz konusu olduğunda, kamu tüzel kişiliğinin örneğin sadece belediye gibi teşkilat, görev ve yetkileri önceden bir kanunla belirlenmiş bir kamu tüzel kişisi mi olacağı; yoksa teşkilat, görev ve yetkileri ile birlikte yeni bir tüzel kişilik mi olacağı sorusunun cevaplanması gerekir. Belediye gibi teşkilat, görev ve yetkileri kanunla belirlenmiş bir kamu tüzel kişiliğinin kararname ile kurulması mümkün olmasa gerekir. Böyle bir durumda kararnamenin bir kanuna dayanması ve kanuna uygun olması esası geçerli olacaktır. Oysa kararnameler asli düzenleme yetkisinin ürünü olarak bir kanuna değil, Anayasa’ya uygun olmak zorundadır. Kararnamelerin Anayasa’ya uygunluğunu da Anayasa Mahkemesi denetleyecektir. O halde belediyenin kurulması ya da kaldırılmasına ilişkin uyuşmazlıklar anayasa yargısının değil, idari yargının görevi olmalıdır. Nitekim 5393 sayılı Belediye Kanunu'nun 4. ve 11. maddesi belediyenin kurulması ve kaldırılmasının "Cumhurbaşkanı kararnamesi” ile değil "Cumhurbaşkanı kararı” ile olacağını düzenlemiş bulunmaktadır. Yine 233 sayılı Kamu İktisadi Teşebbüsleri Hakkında Kanun Hükmünde Kararname’nin 3/1. maddesine göre kamu iktisadi teşebbüsleri "Cumhurbaşkanınca kurulur." "Cumhurbaşkanınca kurulur" ifadesi yeterince açık olmasa da bunu Belediye Kanunu’ndaki gibi “Cumhurbaşkanı kararı” ile kurulur şeklinde anlamak gerekir.

\footnotetext{
Ulusoy, bir "kamu hizmetinin” Anayasa'nın 123/1. maddesi uyarınca kanunla kurulabileceğini, kararname ile kurulmasının mümkün olmadığını ifade etmektedir. Ulusoy (dn 13) 470. Ancak, kamu tüzel kişiliğinin kuruluşunu bir kamu hizmetinin kurulmasından ayrı tutmak mümkün olmasa gerekir. Kamu tüzel kişiliği ile birlikte bir kamu hizmeti de kurulduğunda, söz konusu kamu hizmetinin temel hak ve özgürlüklere yönelik doğrudan bir sınırlama getirme niteliğinde sahip olmaması gerekir.

91 İki düzenleme arasındaki fark, Anayasa değişikliğine uyum için yapılan mevzuat değişikliklerinde terminoloji birliği bulunmadığına örnektir.
} 
Aslında buradaki esas sorun kanunun, kamu tüzel kişiliğini kurma konusunda yürütmeye yetki verip veremeyeceğine ilişkindir ${ }^{92}$. Gerçekten Anayasa'nın 123/4. maddesi değişiklikten önce kanunun verdiği yetki ile idari işlemle de kamu tüzel kişiliğinin kurulabileceğini düzenlemişken; değişiklikten sonra kurucu iradenin biçimini "kanun" ve "kararname” şeklinde sınırlandırmış görünmektedir. Anayasa'nın 123/3. maddesinin ilk haline göre de "kanunun verdiği yetki" açıklığ 1 olmasaydı da belediye gibi görev yetki ve teşkilatı önceden kanunla belirlenmiş bir kamu tüzel kişiliğinin kuruluşunun idari işleme bırakılmasının yasama yetkisinin devredilmezliği ve idarenin kanuniliği ilkeleri bakımından Anayasa'ya aykırı olmayacağını ileri sürebilirdik. Bu bakımdan kanunun görev, yetki ve teşkilatını detaylı bir şekilde düzenlediği ve aynı nitelikte ihtiyaca göre çok sayıda kurulabilecek olan kamu iktisadi teşebbüsü ve belediye gibi kamu tüzel kişiliklerinin kurulmasını idari işleme bırakabilir³. Ancak bu idari işlemin yukarıda açıklanan sebeplerle Cumhurbaşkanlığı Kararnamesi şeklinde olması mümkün değildir.

\section{Sonuç}

Toplumun belli kesimlerinde güçlü ve ihtiyaçlara daha hızlı yanıt veren bir devlet işleyişinin öncelikle güçlü bir yürütme işleviyle mümkün olacağına dair yersiz bir kanı vardır. Bu çalışmada ele aldığımız Anayasa değişikliği bu yersiz kanının bir ürünüdür. Güçlü devlet, hükümet sistemi ne olursa olsun içkin bir hukuk devleti kavrayışla ve yasama işlevinin üstünlügüu ile mümkündür. Yürütme organı ve işlevine ilişkin tasarımlarımız ikinci sırada bir öneme sahiptir.

Ele aldığımız Anayasa değişiklikleri ile beliren yürütmeyi güçlendirme çabasının, zorunlu olmadığı halde düzenleme yetkisini de ele alması şaşırtıcı olmamıştır. Yapılan değişiklikler, anayasal boyutta bugüne kadar varlığını sürdüren idarenin kanuniliği ilkesine istisna getirme sonucunu doğurmuştur. Diğer bir deyişle, düzenleme yetkisinin kanuna dayanması ve sınırlarının kanunla belirlenmesi gerekliliği terk edilerek yürütme erki asli düzenleme yetkisine sahip kılınmıştır. Oluşturulan asli düzenleme yetkisi ile Cumhurbaşkanı yasama organının düzenleme yetkisine ortak kılmıştır. Ancak söz konusu ortaklığın eşit bir ortaklık olmadığı; kanun üstünlüğünün korunduğu, zaten aksinin de düşünülemeyeceği açıktır. Bununla birlikte kanun üstünlüğünün korunması bu üstünlüğün ifade edildiği tutarlı ve açık düzenlemelerle mümkündür. Belirsizlik, Cumhurbaşkanının asli düzenleme yetkisinin genişlemesine yol açacaktır. Düzenleme yetkisini genişletme eğilimi yürütme fonksiyonunun doğasında vardır.

Anayasa değişikliğinin kararnamelere ilişin düzenlemelerinde birçok belirsizlik vardır. Bu belirsizliklerden birisi Anayasa'nın konusunu özel olarak belirlediği kararnamelerin, 104/17. maddesinde genel olarak düzenlenen kararnamelerden bir

\footnotetext{
92 Yasin $(\mathrm{dn} 35) 322$.

93 Aynı yönde bkz. Yasin (dn 35) 323. Aksi yönde bkz. Gözler (dn 23) 318.
} 
farklılık taşıyıp taşamadığına ilişkindir. Bu kapsamda belirlenen özel konularda Kanun Koyucunun kanun çıkarma yetkisinin bulunup bulunmadığı; diğer bir deyişle yürütme için mahfuz bir düzenleme alanının bulunup bulunmadığı yeterince açık bir şekilde düzenlenmemiştir. Anayasa'nın 104/17. maddesinde geçen "münhasıran kanunla düzenlenmesi gereken konular", "yürütme yetkisine ilişkin konular" ve "kanunda açıkça düzenlenen konular" ifadeleri kararnamelerin konu bakımından yetki sınırlarını belirlemek için yeterli olmamıştır.

Ele aldığımız düzenlemelerin yerindeliği bir tarafa, yürütme organının sınırlı düzeyde de olsa asli bir düzenleme yetkisine sahip k1lınması Kanun Koyucunun takdirinde olan bir konudur. Asıl sorun ciddi bir değişimin, değişimin ciddiyetine uygun bir özenle yapılıp yapılmadığına ilişkindir. Neresinden bakarsak bakalım bütün bir hukuk isteminin kurucu iradesini oluşturan Anayasa'da yapılan değişiklerin bir anayasanın taşıması gereken ciddiyetten uzak, nitelikli bir hukuk aklını yansıtmayan, teknik açıdan son derece sorunlu ve belirsizliklerle dolu olduğu daha ilk bakışta görülebilir. Bu nedenle ele almaya çalıştığımız düzenlemelerle ilgili olarak yapılacak her türlü yorum mutlaka eleştiriye açık olacaktır. Yapılacak her yorum bir başka açıdan belli eksiklikler taşıma zaafından kurtulamayacaktır. Bize düşen elimizdeki metni nesnel ölçüler dahilinde, kamu hukukunun bilinen müessesleri ve kavramları çerçevesinde belli bir anlama kavuşturmaya çaba sarf etmektir.

Hukuk devletinin önemli bir özelliği hukuksal belirlilik ve öngörülebilirlik olduğu şüphesizdir. Ele aldığımız Anayasa değişikliği hükümlerinin temel amacının yürütme işlevini güçlendirmek olduğu düşünüldüğünde yaratılmış olan anayasal belirsizliğin doğurduğu endişe bir kat daha artmaktadır. Çalışmamızdan kararnamelere ayrılan münhasır alanın ve düzenleme konularının sınırlı düzeyde tutulduğu sonucu çıkmış olsa da bu bizim yorum çabamız ve bakış açımızdan böyledir. Esas sorun, bu düzenlemelerin yarattığı belirsizliklerin bizim ulaştı̆̆ımız sonucun tam aksine kararnamelerin gücü ve konusu bakımından bambaşka sonuçlarla anlaşılma tehlikesidir. $\mathrm{Bu}$ tehlikeyi bertaraf etmek öncelikle Anayasa Mahkemesinin görevidir.

Düzenlemelerin beraberinde getirdiği anayasal belirsizlik karşısında Anayasa Mahkemesini sakatlanmış bir anayasayı işler hale getirmek gibi zorlu bir görev beklemektedir. Umulur ki yasama işlevinin ve kanunun üstünlüğüne dair hassasiyet bu zorlu görevin ifasında belirleyici bir zemin olsun. Her durumda, geçmişi ve bugünü ile son derece yıpratıcı tartışmaların konusu olan Anayasa Mahkemesi çok daha yıpratıcı eleştirilerin hedefi haline gelecektir. 
Hakem Değerlendirmesi: Dış bağımsız.

Çıkar Çatışması: Yazar çıkar çatışması bildirmemiştir.

Finansal Destek: Yazar bu çalışma için finansal destek almadığını beyan etmiştir.

Peer-review: Externally peer-reviewed.

Conflict of Interest: The author has no conflict of interest to declare.

Grant Support: The author declared that this study has received no financial support. 


\section{Bibliyografya/Bibliography}

Ardıçoğlu A, ‘Cumhurbaşkanlığı Kararnamesi’ (2017) 3 Ankara Barosu Dergisi 21-51.

Aslan V, 'Cumhurbaşkanlığı Kararnamelerinin Kanunlara Uygunluğunun Denetimi ve Çeşitli Hususların Kararname ile Düzenleneceğinin Kanunlarda Belirtilmesi Üzerine’ (2019) 36(1) Anayasa Yargis1 139-161.

Atar Y, ‘Cumhurbaşkanlığı Kararnamelerinin Hukuki Rejimi ve Anayasallık Denetimi’ (2019) 36(1) Anayasa Yargis1 241-260.

Duran L, 'Düzenleme Yetkisi Özerk Sayılabilir mi?’ (1983) 4(1-3) İdare Hukuku ve İlimleri Dergisi $33-42$.

Eren A, 'Anayasa Mahkemesinin Kanun Hükmünde Kararnamelere İlişkin İçtihadı Doğrultusunda Cumhurbaşkanlığı Kararnamelerinin Değerlendirilmesi’ (2019) 36(1) Anayasa Yargısı 1-72.

Ergül O, 'Yeni Rejimin Kodları: Cumhurbaşkanlığı Kararnameleri' (2018) Eylül-Ekim Güncel Hukuk 30-32.

Eroğul C, “TBMM YGK'lerde Değişiklik Yapabilir mi?” (2005) 60(3) Ankara Üniversitesi Siyasal Bilgiler Fakültesi Dergisi 109-121.

Gözler K, Anayasa Hukuku (2. Bası, Ekin 2018).

Günday M, İdare Hukuku (10. Bas1, İmaj 2011).

Güneş T, Türk Pozitif Hukukunda Yürütme Organının Düzenleyici İşlemleri (AÜSBF 1965).

Kanadoğlu K, 'Cumhurbaşkanlığı Kararnamesi' (2018) 2 Galatasaray Üniversitesi Hukuk Fakültesi Dergisi 637-650.

Özbudun E, Türk Anayasa Hukuku (17. Bas1, Yetkin 2017).

Öztürk, BK, Fransız ve Türk İdare Hukukunda Düzenleme Yetkisinin Kapsamı (Yetkin 2009).

Sağlam F, Temel Hak ve Hürriyetlerin Sınırlanması ve Özü (AÜSBF 1982).

Sancaktar O, İdare Hukuku (7. Bası, Seçkin 2018).

Sezer A, 'Normlar Hiyerarşisi ve Cumhurbaşkanlığı Kararnameleri [Çok Boyutlu Normlar Piramidi Yaklaşımı]' (2019) 36(1) Anayasa Yargısı 353-412.

Söyler Y, Yeni Başkanlık Sisteminde Cumhurbaşkanlığı Kararnamesi (Seçkin 2018).

Şirin T, ‘İşlemeyen Sistemlerin Fonksiyonel Olmayan Yanıtı: Cumhurbaşkanlığı Kararnamesi’ (2018) 7(14) Legal Anayasa Hukuku Dergisi 289-356.

Taşdöğen S, ‘Cumhurbaşkanlığı Kararnameleri' (2016) 65(3) Ankara Üniversitesi Hukuk Fakültesi Dergisi 937-966.

Teziç E, Türkiye’de 1961 Anayasasına Göre Kanun Kavramı (IÜHHF 1972).

Tunç H, Türk Anayasa Hukuku (Gazi 2018).

Ulusoy A, Ali Ulusoy, Yeni Türk İdare Hukuku (Yetkin 2019).

Ülgen Ö, ‘Cumhurbaşkanlığı Kararnameleri: İlk Gözlemler’ (2018) 2 Galatasaray Üniversitesi Hukuk Fakültesi Dergisi 619-635.

Ülgen Ö, 'Cumhurbaşkanlığı Kararnamelerinin Niteliği ve Türleri' (2018) 1 Galatasaray Üniversitesi Hukuk Fakültesi Dergisi 3-39.

Ülgen Ö, 'Kanun-Cumhurbaşkanlığı Kararnamesi İlişkisinin Yargısal Denetimine Yönelik Sorunlar' (2019) 36(1) Anayasa Yarg1s1 261-277.

Yasin M, ‘Cumhurbaşkanlığı Kararnamelerinin Türk İdari Teşkilat Hukukuna Etkileri’ (2019) 36(1) Anayasa Yargis1 315-333. 
Yıldırım T, 'İdarenin Kanuniliği İlkesi Bağlamında Cumhurbaşkanlığı Kararnamelerinin Anayasal Sinırı’ (2019) 36(1) Anayasa Yargısı 293-314.

Yıldırım T, Cumhurbaşkanlığı Kararnameleri' (2017) 23(2) Marmara Üniversitesi Hukuk Fakültesi Hukuk Araştırmaları Dergisi 13-28.

Yılmaz H, ‘Cumhurbaşkanlığı Kararnamelerinin Yargısal Denetimi’, (2019) 7(13) Antalya Bilim Üniversitesi Hukuk Fakültesi Dergisi 373-392. 
